\title{
Empreendedorismo: O Perfil do Empreendedor e a Longevidade da Empresa - Estudo de Caso da Empresa Multi Formato Distribuidora S/A e de seu Presidente ${ }^{[1]}$
}

MORAIS, Agnaldo Barbosa ${ }^{[2]}$, MAGELA, Ângela Natalícia de Andrade ${ }^{[3]}$, SANTOS, Gizele Rodrigues dos ${ }^{[4]}$, FERREIRA, Jovane Aparecido ${ }^{[5]}$, CARMO, Lucilene Maria do ${ }^{[6]}$

MORAIS, Agnaldo Barbosa; et.al. Empreendedorismo: O Perfil do Empreendedor e a Longevidade da Empresa - Estudo de Caso da Empresa Multi Formato Distribuidora S/A e de seu Presidente. Revista Científica Multidisciplinar Núcleo do Conhecimento. Edição 07. Ano 02, Vol. 01. pp 142-193, Outubro de 2017. ISSN:2448-0959

\section{RESUMO}

O empreendedorismo é fonte de pesquisa constante junto às ciências sociais aplicadas, em especial, nos estudos da Administração contemporânea. Órgãos como o Global Entrepreneurship Monitor (GEM, 2014), bem como, na realidade brasileira, o SEBRAE (2014), dedicam esforços para compreender as ondas empreendedoras, o perfil do empreendedor, e os fatores que contribuem para a longevidade das empresas. Segundo esses órgãos monitores, a maior parte das empresas brasileiras tem longevidade inferior a três anos. Foi essa informação que gerou o questionamento central para este trabalho de pesquisa. $\mathrm{O}$ intuito era compreender os fatores que influenciam na longevidade organizacional, dedicando maior atenção ao papel do perfil do empreendedor nesse contexto. $\mathrm{O}$ empreendedor passa por diversas fases tais como encontrar, avaliar e desenvolver oportunidades para criar um empreendimento que o satisfaça em suas realizações. A junção dessas fases com as características do empreendedor são objetos desse estudo, em que o referencial teórico foi o suporte para a realização do mesmo. A hipótese foi gerada a partir de uma verdade provisória, ou seja, uma afirmação a respeito de algo desconhecido. Obviamente questões levantadas sobre o perfil empreendedor já foram bastante discutidas, mas a questão a qual os pesquisadores deste trabalho se detém é saber se o perfil do empreendedor influencia ou não na longevidade da empresa, oferecendo um novo parâmetro para esse trabalho. A metodologia aplicada forneceu os meios pelos quais o objetivo geral foi delimitado e concluído, através dos objetivos específicos. Sendo que a entrevista focal, realizada por meio do roteiro, em paralelo ao questionário aplicado aos colaboradores, contribuiu para que, através do confronto entre a coleta de dados e o aporte teórico, fosse possível chegar à conclusão desse trabalho de forma satisfatória. 
Palavras-chave: Empreendedorismo, Perfil Empreendedor, Longevidade.

\section{INTRODUÇÃO}

O significado de empreendedor muda de acordo com o país e a época, no final do século XVII, empreender era "a firme resolução de fazer qualquer coisa", no século XIX e início do século XX, o termo designava os grandes capitães de indústria, tais como Ford nos Estados Unidos da América (EUA), Peugeot na França, Cadbury na Inglaterra, Toyota no Japão. Atualmente, denota a atividade de toda pessoa que está na base de uma empresa, desde o franqueado ou um dono de oficina mecânica, até aquele que criou e desenvolveu uma multinacional (DOLABELA, 2008, p. 59).

Os empreendedores são pessoas que se dispõe a criar oportunidades de mercado e fazer acontecer, lutar pela sua consecução, para pôr em prática suas ideias e gerar um ou mais negócios. Além do que, os empreendedores são essenciais no mercado, pois são agentes de inovação e estimulam a criatividade (DRUCKER, 2002).

O desafio não está somente em conseguir constituir um negócio, mas principalmente em mantê-lo em funcionamento. Isso, muitas vezes, é devido à enorme carga tributária vigente no país, a morosidade dos processos fiscais e, também, a falta de conhecimento do empreendedor nas questões administrativas. Esses são alguns dos fatores que, usualmente, inviabilizam a sobrevivência dos empreendimentos. Só o espírito empreendedor não basta, as possibilidades de se manter um novo negócio com êxito no mercado, por mais de três anos, são relativamente baixas (MAXIMIANO, 2011).

Segundo Degen (2009), os riscos fazem parte de qualquer atividade empresarial e é preciso aprender a administrá-los. O empreendedor não fracassa em seu negócio apenas porque sofre revezes e, sim, porque, muitas vezes, não sabe prever, administrar e superar as dificuldades do negócio. Já, de acordo com Maximiano (2011), o sucesso de um empreendimento pode ser medido por indicadores que se estabelecem por uma cadeia de causas e efeitos, tais como satisfação do cliente e desempenho financeiro, no qual tudo depende principalmente do desempenho gerencial do empreendedor.

O preparo e a autoconfiança do potencial empreendedor para iniciar um negócio próprio são funções diretas de seu conhecimento, domínio sobre as tarefas necessárias para desenvolvê-lo, sua capacidade gerencial, seu domínio sobre a complexidade do negócio e sua experiência acumulada. Esse é um conjunto de características que estão ligadas diretamente a longevidade da empresa, segundo Degen (2009).

São diferentes fatores que determinam o sucesso de um empreendedor, entretanto, de forma constante, podem-se avaliar que, uma pessoa dificilmente chegará ao sucesso se não tiver características mínimas dos empreendedores que já vivenciaram o sucesso. Dentre as características mais apontadas, a inovação ainda ocupa o primeiro lugar, além da capacidade de correr riscos calculados, necessidade de realização e autoconfiança (OLIVEIRA et al., 2012).

O perfil do empreendedor é analisado segundo Degen (2009) por duas dimensões, ou seja, por categoria e pessoal, logo, por categoria são classificados: empreendedor social, empreendedor econômico ou corporativo; e o pessoal, por um conjunto de características e competências, que são variáveis de um indivíduo para outro, que de forma distinta identificam e caracterizam o tipo de perfil do empreendedor. É 
o que também afirma Maximiano (2011).

Observa-se que não é só o perfil empreendedor o fator impactante na longevidade da empresa, mas o trabalho se deteve nesta questão e sendo assim, também não se deteve em um único autor, devido ao número de autores consultados e que de forma genérica estão alinhados nas características que compõe a persona do sujeito da pesquisa, Euler Fuad Nejm.

Desta forma, este estudo busca responder a seguinte pergunta: O perfil do empreendedor Euler Fuad Nejm [7] influência ou não na longevidade da empresa Multi Formato Distribuidora S/A?

Justifica-se que esse estudo, mediante as investigações realizadas, oportunizou maior conhecimento aos integrantes do grupo a respeito da importância dos conhecimentos administrativos na prática empreendedora, bem como se constituiu para essa instituição acadêmica uma visão analítica, de como e se o perfil do empreendedor Euler Fuad Nejm pode influenciar na longevidade da empresa Multi Formato Distribuidora S/A.

O objetivo geral foi pesquisar se o perfil do empreendedor Euler Fuad Nejm influencia na longevidade da empresa Multi Formato S/A. Tendo como objetivos específicos: 1. Pesquisar os tipos de perfis importantes para alguém ser um empreendedor na visão dos teóricos; 2. Identificar o perfil do empreendedor sujeito da pesquisa; 3. Analisar se há influência do perfil do empreendedor sujeito da pesquisa na longevidade da empresa Multi Formato Distribuidora S/A.

Tendo como hipóteses a afirmação de que o perfil do empreendedor Euler Fuad Nejm pode sim influenciar de forma positiva ou negativa na longevidade da empresa Multi Formato Distribuidora S/A, ou, também a hipótese da negação, de que o perfil do empreendedor sujeito da pesquisa não exerce nenhum tipo de influência na longevidade da empresa Multi Formato Distribuidora S/A. Segundo Gil (2009), a hipótese estabelece se há uma relação existente entre duas ou mais variáveis e verifica se uma variável interfere na outra.

\section{METODOLOGIA}

A finalidade da pesquisa foi identificar o perfil do empreendedor Euler Fuad Nejm e se este influencia na longevidade ou sucesso/fracasso da empresa Multi Formato Distribuidora S/A. A metodologia aplicada neste trabalho foi o método indutivo, com análise qualitativa e quantitativa, explicativa, utilizando o estudo de caso como técnica prática. Os instrumentos de coleta de dados possibilitaram registrar, analisar, interpretar fatores que auxiliaram na análise de dados referentes ao assunto pesquisado.

Conforme Gil (1999), o método indutivo é utilizado pela observação de fatos e fenômenos, cujas causas se esperam conhecer. Observação essa, que em seguida, deve ser confirmada na realidade em que foi analisada, com a finalidade de comparar quais as relações existentes entre eles, já a análise qualitativa caracteriza-se como análise por forma de entrevista, de maneira não estruturada podendo sofrer alterações no decurso e trata das características individuais, desde que a mesma consiga obter as informações necessárias para as possíveis soluções do problema em questão.

Ainda de acordo com Gil (1999), as pesquisas explicativas têm como objetivo principal identificar os fatores que determinam ou que contribuem para a ocorrência dos fenômenos que aprofundam o 
conhecimento da realidade. Elas esclarecem a razão, o porquê das coisas. Por esse motivo são complexas e delicadas, onde os riscos de se cometer erros aumentam consideravelmente.

Severino (2007) enfatiza que o estudo de caso é um estudo mais detalhado do objeto da pesquisa e que complementa as etapas de uma pesquisa, de forma prática, pois explora situações da realidade dentro do contexto analisado, na tentativa de explicar suas variáveis. As análises podem ser utilizadas por diferentes metodologias e estabelecidas em distintos problemas, atrelados a crenças, conhecimento, natureza e limitações.

Entretanto Gil (1999) define que o estudo de caso se caracteriza por um estudo individual, exaustivo de um ou mais objetos, de forma a admitir o seu conhecimento extenso e detalhado, ressaltando assim suas vantagens, contudo tem-se como desvantagem a dificuldade de generalização, pois só se aplica ao objeto da pesquisa, o que nesse trabalho é o Sr. Euler Fuad Nejm, proprietário da empresa Multi Formato Distribuidora S/A. Assim sendo, as constatações de um estudo de caso não são conclusivas para os demais casos estudados, ainda que sejam semelhantes.

Segundo Andrade (2010) definir os instrumentos de pesquisa e conhecer seus métodos de aplicação são etapas fundamentais para um estudo de caso com mais abrangência do assunto. Seja qual for o método ou métodos escolhidos, é imprescindível que as perguntas elaboradas sendo elas do questionário, formulário ou roteiro sejam claras e objetivas, afim de que as respostas correspondam às expectativas de compreensão do assunto abordado.

Além das consultas em mídias e revistas, também foi realizada uma entrevista com o Sr. Euler Fuad Nejm, para que fosse possível averiguar as duas variáveis desta pesquisa: 1) qual é o perfil do empreendedor Euler Fuad Nejm e 2) sua influência na longevidade da empresa Multi Formato Distribuidora S/A. Também foram aplicados questionários em cinco colaboradores vinculados ao empreendedor.

A escolha dos funcionários foi realizada de forma intencional objetivando contemplar diferentes níveis de aproximação e posicionamento na hierarquia organizacional, sendo: Nível 1 (Vínculo estritamente profissional de ordem direta) - 1 colaborador; Nível 2 (Vínculo estritamente profissional de ordem indireta) - 1 colaborador; Nível 3 (Vínculo profissional de ordem direta) - 1 colaborador; Nível 4 (vínculo profissional/pessoal de ordem direta) - 2 colaboradores.

Foi utilizada como um dos instrumentos de coleta de dados a entrevista focal, para a qual elaborou-se um roteiro com os tópicos que seriam abordados a fim de obter orientação para a "conversa". Este tipo de entrevista confere mais liberdade tanto para o pesquisador quanto para o entrevistado. As perguntas não são rigidamente formuladas, o entrevistado pode alongar-se em determinados tópicos, trazendo mais informações e a entrevista transcorre mais como conversa informal, mesmo quando o roteiro é obedecido (ANDRADE, 2010).

Já o questionário confere uma menor possibilidade de respostas ao pesquisado, vide a formulação de perguntas fechadas ou semiestruturadas, com a indicação de respostas pré-definidas. Dessa forma, as perguntas fechadas devem ser muito claras e objetivas. A preferência deve recair sobre o emprego de perguntas fechadas, ou seja, as que pedem respostas curtas e previsíveis (ANDRADE, 2010). 
Portanto, os resultados desta pesquisa foram obtidos através da análise da entrevista realizada com o senhor Euler e a comparação desta com os conceitos de autores que lecionam sobre o assunto empreendedorismo, além das impressões dos colaboradores obtidas após a aplicação de questionários.

A análise de dados é a interpretação dos dados coletados entre o referencial teórico e a prática da pesquisa. É o processo de confrontar informações, ação que envolve identificação, coordenação e filtragem dos dados que foram adquiridos por meio das buscas bibliográficas, pesquisa de campo, realização de entrevistas e/ou aplicação de questionários, estudo de caso, dentre outros, conforme Gil (2009).

De acordo com Vergara (2006) a análise de dados é feita logo após obter as respostas do objeto da pesquisa, ou seja, por questionário e/ou entrevista, dos fatos observados e da reunião teórica sobre o assunto. A análise se constitui nas inferências posteriores ao cruzamento de todos os dados obtidos, para que seja possível responder a pergunta e as hipóteses levantadas inicialmente.

\section{REFERENCIAL TEÓRICO}

\subsection{Definição de empreendedorismo}

O que define empreendedorismo é um processo que gera riqueza. O que deve ser algo que agregue valor para o empreendedor e para a sociedade, podendo ser ou não novo e/ou único de um produto ou serviço, mas que exige tempo e esforço do empreendedor. Uma vez que emprega tempo, habilidades e recursos necessários, o empreendedor espera satisfação financeira e pessoal; e também deve estar preparado para um possível fracasso, diferente do perfil de inventor que não se empenha no processo de implantação e comercialização, mas sim da criação de novos produtos e serviços (HISHICH; PETERS; SHEPHERD, 2009).

Ainda de acordo com Hishich, Peters e Shepherd (2009) o empreendedorismo tem um papel importante no desenvolvimento econômico de um país, pois envolve mudanças na estrutura do negócio e da sociedade, pois além de promover riquezas, também é provedor das mudanças do estilo de vida e de comportamento de consumo de produtos e serviços devido às melhorias que oportuniza, feito este adquirido através de inovações comuns, tecnológicas ou incrementais; ou seja: evolução do produto ou serviço.

Segundo Fillion (2000), o empreendedorismo é o principal fator para o desenvolvimento de uma sociedade, trata-se de buscar oportunidades e recursos a fim de transformar uma ideia em um negócio rentável, o empreendedor tem como principal característica um espírito inovador e destemido e busca constantemente por inovações e novas perspectivas para seu negócio, porém para ter sucesso é preciso iniciativa, visão, coragem, firmeza e capacidade de organização e direção.

O empreendedor e o empreendedorismo possuem dois cursos de visualização, primeiro há os economistas, que associam o empreendedor ao desenvolvimento econômico e à inovação; segundo há os comportamentalistas, que associam a atitude, criatividade, intuição e disposição de correr riscos. Sobre a visão de Cantillon [8] (1755 apud MAXIMIANO, 2011, p. 3), "o empreendedor é aquele que assume riscos na compra de produtos ou serviços com preço certo e revenda posterior por preço incerto". 
O empreendedor é capaz de explorar novas tecnologias, materiais e preços de forma a agregar valor ao produto ou serviço, alterando assim recursos econômicos de áreas de baixa produtividade e transformá-la em área de ampla lucratividade, o que torna decisiva a função do empreendedor na empresa, na economia de uma sociedade, um país, segundo Say [9] (1888 apud MAXIMIANO, 2011, p. 2):

O que fazem os empreendedores? Eles usam sua indústria (ou seja, seu trabalho) para organizar e dirigir os fatores de produção, de forma a atender as necessidades humanas. No entanto, eles não são apenas dirigentes. São também planejadores, avaliadores de projetos e tomadores de riscos. Usando seu próprio capital, ou o que emprestam de outros, eles o transferem para proprietários do trabalho, os recursos naturais (terra) e maquinário (ferramentas). Esses pagamentos, ou alugueis, somente são recuperados se os empreendedores conseguem vender o produto para os consumidores. $\mathrm{O}$ sucesso empresarial não apenas é almejado pelo indivíduo, mas também é essencial para a sociedade. Um país com muitos comerciantes, fabricantes e agricultores inteligentes tem maiores possibilidades de alcançar a prosperidade do que outro que se dedique principalmente à busca das artes e ciências.

Empreendedores não são inventores, são inovadores capazes de introduzir novos produtos, novos meios de produção, novas formas de organização à variedade. E por saber como usar novas invenções, possuem a capacidade de promover o progresso do padrão de vida da coletividade. O empreendedor ao mesmo passo que é criativo também é prático desde o início, crescimento e sobrevivência do empreendimento. Habilidade e ousadia são características que distinguem o empreendedor segundo Schumpeter[10] (1942 apud MAXIMIANO, 2011, p. 3).

O processo do empreender não envolve só a identificação de uma oportunidade em potencial, mas a de superar as forças de resistência à criação de algo novo ou de melhorar algo já existente com certa deficiência, ainda que progressivamente o empreendedor deva ater-se às quatro fases distintas do empreendedorismo, sendo elas a de identificar e avaliar a oportunidade, desenvolvimento do plano de negócio, determinar os recursos necessários e administrar o empreendimento resultante (HISRICH; PETERS; SHEPHERD, 2009).

De acordo com Britto e Wever (2003, p. 13), em um país onde a maioria da população maior de 18 anos quer ter independência financeira e ser reconhecida por seu feito, empreender é coisa recorrente "O Brasil é por excelência, o país do empreendedorismo". O grande sonho de milhões de brasileiros, não importando gênero, crença ou idade é ser dono de seu nariz, ter seu próprio negócio, participar de um projeto, criar, empreender.

Em relação à condição brasileira, o empreendedor no país deve sempre ter em mente uma estratégia para o desenvolvimento de sua ideia como negócio. Nesse sentido, o termo empreendedor é uma estratégia, que tem sua definição como a habilidade de aplicar os meios disponíveis com vistas à consecução de objetivos específicos, trata-se da arte de explorar condições favoráveis como o fim de alcançar o objetivo proposto, determinado (DORNELAS, 2008).

\subsection{Perfil Empreendedor}

Há uma diversidade de perfis de empreendedores, mas ter visão de inovação é primordial para qualquer empreendedor, seja ele iniciante ou de longa experiência no mercado, pode-se identificar características e competências essenciais de um empreendedor, umas mais que outras dependendo de cada indivíduo, 
"alguns nascem predestinados a se tornar empreendedores, demonstram que é possível se tornar um deles em qualquer fase da vida" outros adquirem a capacidade semelhante (MENDES, 2012, p. 52).

Maximiano (2011) afirma que o perfil do empreendedor é um comportamento combinado, manifestado e em grau de intensidade de formas diversas em diferentes pessoas. Traços de comportamento esses que integram as competências necessárias ao desenvolvimento do empreendedor. Os principais traços de comportamento do empreendedor são: criatividade e capacidade de implementação; disposição para assumir riscos; perseverança e otimismo; senso de independência.

De acordo com Degen (2009), o perfil do empreendedor se diferencia do da maioria das pessoas por seu jeito peculiar de ser, estão dispostos a assumir riscos, não que ele não calcule os riscos, ao contrário, ele tem a visão de negócio e se houver chance de dar certo ele assume os riscos do negócio e abre mão de várias coisas para ter sucesso em seu empreendimento. Seja a motivação ganhar dinheiro ou simplesmente realização pessoal, está sempre interligado ao empreendedorismo social, econômico ou coorporativo independente de seu perfil pessoal.

O perfil do empreendedor bem-sucedido não pode ser tomado como um padrão de exigências. Ele deve ser usado exclusivamente para descobrir para onde direcionar o processo de desenvolvimento, detectando o que precisa ser aperfeiçoado e trabalhado para ser o empreendedor que espera ser. $\mathrm{O}$ empreendedor bemsucedido é uma pessoa como qualquer outra, cujas características de personalidade, talentos e habilidades o leva a agir de tal forma que chega ao sucesso, realizando sonhos, alcançando seus objetivos e atingindo sua realização pessoal. (GREATTI, 2013, p. 63).

A organização e o senso crítico também fazem parte deste contexto, compreender as relações internas e entender as alterações ocorridas no meio ambiente externo, antecipando aos problemas principais e analisando-os friamente são aspectos imprescindíveis a um empreendedor. Entretanto, para o empreendedor é necessário ir além da capacidade de dominar a transformação de uma organização já existente, é preciso saber agir em situações de políticas, públicas e motivação de pessoas que possuam objetivos avessos aos seus, onde os recursos são limitados. "Isto exige capacidade de liderança que mesmo o empreendedor privado mais bem-sucedido pode ter dificuldades em reunir" (BIRLEY; MUZYKA, 2001, p. 276).

$\mathrm{Na}$ atualidade, para se manter competitivo é necessária a inovação, o indivíduo não tem a necessidade de abrir seu próprio empreendimento, mas pode atuar na organização onde trabalha inovando, sendo criativo e com um olhar diferenciado sobre tudo. O empreendedorismo corporativo é um meio de estimular e aproveitar os indivíduos em uma organização que entendem que algo pode ser feito de maneira diferente e melhor. A empresa que estimula as ações empreendedoras do seu funcionário ganha em aperfeiçoamento e inovação, além de manter o funcionário motivado (HISHICH; PETER; SHEPHERD, 2009).

Estes mesmos autores Hishich, Peter e Shepherd (2009) salientam que criar essa cultura de estimular o empreendedorismo corporativo não é algo fácil que ocorra da noite para o dia. É necessário que haja o comprometimento de todos os níveis organizacionais e que haja ações eficazes para transformar a cultura organizacional em cultura empreendedora, além de criar um ambiente propício para identificar, incentivar e não perder esses talentos. 
Para Dornelas (2007), se não houver envolvimento de todos os níveis hierárquicos na execução dos objetivos propostos, dificilmente haverá bons resultados. É necessário que haja ações com foco nos processos e principalmente nas pessoas, que devem se sentir motivadas e seguras para agirem de forma empreendedora, muitas vezes assumindo os riscos e possibilidades de fracassar, mas se guiando pela certeza de reconhecimento. Neste contexto pode-se descrever o empreendedor como alguém flexível, com facilidade de trabalho em equipe, diplomático e incentivador.

O autor ainda é enfático ao alegar que o empreendedor é aquele que se antecipa aos fatos, tem uma visão futura da organização e que realmente faz com que as coisas aconteçam. Deste modo, aponta aspectos fundamentais das habilidades, competências e características que moldam o perfil empreendedor:

As habilidades requeridas de um empreendedor podem ser classificadas em três áreas: tarefas: técnicas, gerenciais e características pessoais. As habilidades técnicas envolvem saber escrever, saber ouvir as pessoas e captar informações, ser um bom orador, ser organizado, saber liderar e trabalhar em equipe e possuir know-how técnico na área de atuação. As habilidades gerenciais incluem as áreas envolvidas na criação, desenvolvimento e gerenciamento de uma nova empresa e características pessoais como ser: disciplinado, assumir riscos, ser inovador, ser orientado a mudanças, ser persistente e ser um líder visionário formam a base para o empreendedorismo do próprio negócio. (DORNELAS, 2014, p. 30).

Segundo Charan (2007), os traços de perfis interagem entre si e com o know-how (saber como), quando se percebe estas interligações está apto a detectar as tendências externas ou o que afeta o posicionamento da empresa, criar novas oportunidades, além de ser capaz de ver a empresa de forma holística e não como unidades ou indivíduos separados. Ele acrescenta que os atributos pessoais são apenas uma pequena parte da questão de liderança e que esses atributos diminuem muito o seu valor sem o know-how, ou seja, sem os conhecimentos adquiridos e inter-relacionados que introduzem liderança ou espírito criativo no âmbito de lucros e perdas.

Know-how é o que separa os líderes realizadores - que produzem resultados - dos não-realizadores. É a característica inconfundível daqueles que sabem o que estão fazendo, que criam valor intrínseco de longo prazo e alcançam metas de curto prazo. O que atrapalha a descoberta de profissionais realizadores é a aparência e liderança. Muitas vezes, vejo pessoas serem escolhidas para cargos de liderança com base em características pessoais superficiais. (CHARAN, 2007. p. 1).

Wagner (2009) em seus estudos afirma que a personalidade aplicada a um comportamento organizacional está focada em cinco grandes dimensões da individualidade como: extroversão, ajustamento emocional, afabilidade, senso de responsabilidade e interesse; e acrescenta que a aptidão cognitiva é associada a três fatores: percepção, decisão e criatividade os quais são vieses e pelo que se pode entender melhor o efeito da personalidade de um sujeito perante a um cargo ou situação de risco.

O Serviço Brasileiro de Apoio às Micro e Pequenas Empresas (SEBRAE, 2015), descreve que o perfil do empreendedor pode ser definido em criatividade, liderança, perseverança, flexibilidade, automotivação. Outro aspecto fundamental do empreendedor é a formação permanente, a busca constante de informações sobre o mercado e atualização profissional sobre novas tecnologias gerenciais, o que reforça que "o talento empreendedor resulta da percepção, direção, dedicação e muito trabalho. Onde existe esse talento, há a oportunidade de crescer, diversificar e desenvolver novos negócios" (DORNELAS, 2014. p. 29). 
Dornelas (2014. p. 29), completa que:

O processo empreendedor envolve todas as funções, atividades e ações associadas à criação de novas empresas. Em primeiro lugar, o empreendedorismo envolve o processo de criação de algo novo, de valor. Em segundo, requer a devoção, o comprometimento de tempo e o esforço necessário para fazer a empresa crescer. Em terceiro, que riscos calculados sejam assumidos, e decisões críticas, tomadas: é preciso ousadia e ânimo, apesar de falhas e erros.

A criatividade é aceitar desafios e buscar soluções viáveis para o equacionamento de problemas, ou seja, soluções criativas para um problema raramente surgem do nada, pois as inovações são geralmente induzidas por um problema ou pela percepção de uma necessidade. Já a liderança é inspirar confiança, motivar, delegar responsabilidades, compartilhar ideias no âmbito de uma organização, bem como formar equipes além da capacidade de ouvir, aceitar opiniões, elogiar e criticar pessoas num contexto de clima de padrão moral elevado (SEBRAE, 2015).

A grande tarefa do líder consiste em ter a habilidade de coordenar as atividades de cada membro em particular, a fim de que a atividade grupal flua de forma normal e sem interrupções, ao mesmo tempo em que se verifique um clima de harmonia no tocante à participação de cada um. (BERGAMINI, 1982. p. 98).

Percepção é o processo pelo qual os indivíduos selecionam, organizam, armazenam e recuperam informações. Decisão é o processo pelo qual as informações percebidas são utilizadas para avaliar e escolher entre vários cursos de ação. Criatividade é o processo de combinar ou associar ideias de um modo novo, incomum. (WAGNER, 2009, p. 58).

Perseverança como a capacidade de manter-se firme em seus propósitos, sem deixar de enxergar os limites de sua possibilidade, buscando metas viáveis sempre que for confrontado com situações adversas. A flexibilidade em controlar seus impulsos para ajustar-se quando a situação demandar mudanças, estar aberto para estudar e aprender sempre. Outro componente dentro dos aspectos fundamentais do empreendedor é a formação permanente, ou seja, a busca constante de informações sobre o mercado e atualização profissional sobre novas tecnologias gerenciais (SEBRAE, 2015).

\subsubsection{Tipos de perfis empreendedores}

Para que se possa entender sobre o tipo de perfil de um empreendedor, é imprescindível ter um breve conhecimento sobre suas características. Podem-se identificar características essenciais de um empreendedor, umas mais que outras dependendo de cada indivíduo, até mesmo porque algumas são natas e outras adquiridas por instrução. O empreendedor deve ser autoconfiante, íntegro, visionário, responsável, disciplinado, focado, dentre outras características apontadas por Mendes (2012, p. 58):

Autoconfiança: acreditar em si mesmo e nas possibilidades do negócio é a maior das virtudes.

Disciplina: sem disciplina ninguém vai a lugar algum.

Foco: empreendedores não titubeiam nem ficam pulando de galho em galho tentando acertar o alvo mais fácil. 
Liderança: estabelecer metas, definir propriedades, determinar e manter padrões, são tarefas essenciais do líder para atingir objetivos.

Integridade: é a correspondência entre seus valores e sua conduta.

Otimismo: a base do otimismo são a convicção e a autoconfiança, entretanto, ser otimista não significa ser irresponsável, mas ser positivo em relação aos obstáculos e às oportunidades.

Paixão pelo que faz: quando você gosta do que faz, a dedicação é tanta que o sucesso é a única saída.

Persistência: o erro faz parte do aprendizado, portanto, em qualquer negócio você vai errar. O sucesso é construído de pequenos erros e acertos todos os dias.

Responsabilidade: ser responsável significa saber assumir as consequências de seus atos.

Visão: a maioria dos empreendedores de sucesso visualizam os negócios para cinco, dez ou vinte anos à frente do seu tempo, e isso faz toda a diferença.

Segundo Hashimoto (2010, s.p.), "nenhum empreendedor é completo. Todos eles têm falhas, defeitos, problemas, como qualquer um de nós". Ocorre é que os empreendedores possuem uma ou mais característica, não todas. Por este motivo pode-se afirmar que um empreendimento de sucesso pode agrupar mais do que um perfil. "Dificilmente as pessoas possuem o mesmo tipo de perfil ao longo do tempo. Suas vivências e experiências vão proporcionando condições para enfatizar outros tipos de perfis com o tempo", o que os leva aos tipos de perfis é o conjunto, podendo classificá-los em cinco tipos de perfis empreendedores, como observa-se no quadro 1 :

Quadro 1 - Tipos de perfis Empreendedores

\begin{tabular}{|c|c|}
\hline Empreendedor Criativo & $\begin{array}{l}\text { São empreendedores cheios de ideias, de } \\
\text { imaginação fértil, grande capacidade de descobrir } \\
\text { novos pontos de vista, enxergar o que ninguém vê, } \\
\text { identificar oportunidades e pensar em soluções } \\
\text { surpreendentes. São pessoas que possuem uma } \\
\text { visão singular do mundo, que conseguem se } \\
\text { adaptar facilmente às mudanças e que vivem no } \\
\text { mundo da lua, sempre imaginando futuros } \\
\text { brilhantes. Por outro lado, falta-lhes a visão } \\
\text { pragmática, a capacidade de colocar suas ideias em } \\
\text { prática, de partir para a ação e de engajar outras } \\
\text { pessoas em seus devaneios. }\end{array}$ \\
\hline Empreendedor Administrador & São os empreendedores que pegam a ideia do \\
\hline
\end{tabular}


criativo e analisam a viabilidade dessa ideia.

Conseguem fazer um estudo minucioso, analisar o mercado, levantar informações, estruturar dados, fazer contas. São metódicos e detalhistas, são formais e organizados. Esse tipo de empreendedor, ao contrário do criativo, tem os pés muito bem fincados no chão, não se arrisca, tem uma visão bastante pragmática e objetiva. Precisa de bons argumentos para se convencer de algo e planos bem estruturados que prevejam o futuro. Eles são ótimos para elaborar planos de negócios, mas péssimos para colocar os planos em prática. Nessas situações, ele demora para dar o primeiro passo, acha sempre que o planejamento não está completo ainda, e acaba paralisado atrás de uma mesa.

São os que põem a mão na massa, querem ver a coisa acontecendo, querem ver resultados. São ágeis, dinâmicos, ativos, nunca têm preguiça, têm muita iniciativa e boa vontade, e estão sempre fazendo mil coisas ao mesmo tempo. São os primeiros a se apresentar quando algo precisa ser feito. Não conseguem ficar parados. utilização de todo o potencial de cada membro, a integração de esforços em torno de objetivos comuns e a exploração da motivação intrínseca que mobiliza cada membro no projeto. São pessoas que servem de inspiração no grupo, reúnem a atenção em torno de si, conseguem engajar pessoas só pelo discurso e empatia. São hábeis em conhecer as pessoas e lidar com elas, também conseguem fazer 


\begin{tabular}{|c|c|}
\hline & $\begin{array}{l}\text { com que cada um dê o máximo de si e organiza } \\
\text { times em que seus membros se complementem uns } \\
\text { aos outros. Podemos dizer que esse tipo de } \\
\text { empreendedor é o líder da equipe, ou seja, nem } \\
\text { todos os empreendedores têm perfil de liderança, } \\
\text { apenas os empreendedores-integradores, um } \\
\text { equívoco muito frequente. }\end{array}$ \\
\hline Empreendedor Promotor & $\begin{array}{l}\text { Sabe se relacionar muito bem com pessoas, tanto } \\
\text { quanto o integrador, porém não com a equipe } \\
\text { interna e sim com a equipe externa, formada por } \\
\text { parceiros, clientes, investidores, fornecedores, } \\
\text { terceiros etc. Seu papel é vender a ideia para obter } \\
\text { recursos (financeiros ou não) e apoio geral para a } \\
\text { ideia. Podemos dizer que ele é o "vendedor" do } \\
\text { grupo. Ele gosta muito de encontros sociais, fala } \\
\text { bastante, tem muitos amigos, prefere fazer negócios } \\
\text { em ambientes informais, cativa, envolve, influencia } \\
\text { e articula muito bem seu discurso. O perfil } \\
\text { promotor sempre vai ser requerido em qualquer } \\
\text { projeto de natureza empreendedora. Porém são } \\
\text { poucos que detêm esta habilidade. Normalmente, } \\
\text { como são os que mais aparecem na imprensa, } \\
\text { frequentemente se acha que o empreendedor tem } \\
\text { obrigatoriamente esse perfil. }\end{array}$ \\
\hline
\end{tabular}

Fonte: Adaptado de Hashimoto (2010, s.p.)

Depois de um tempo, em sua pesquisa, Hashimoto (2013), constatou que os critérios utilizados por estudiosos na caracterização dos diferentes tipos de perfis de empreendedores são baseados em dezesseis modalidades diferentes e que com base nessas modalidades obtém-se uma caracterização mais aproximada do tipo de perfil, pode-se observar as modalidades de caracterização, determinadas no quadro 2:

Quadro 2 - Modalidades de Caracterização 


\begin{tabular}{|c|c|}
\hline & $\begin{array}{l}\text { seu negócio nascente. O empreendedor só pede } \\
\text { demissão depois que tem certeza que sua empresa } \\
\text { vai decolar. Muito comum no Brasil, como forma } \\
\text { de reduzir os riscos. }\end{array}$ \\
\hline Solopreneur & $\begin{array}{l}\text { Trata-se daquele one man show que não consegue } \\
\text { delegar decisões e, por isso, tem dificuldades para } \\
\text { crescer. Artesãos, consultores e artistas, entre } \\
\text { outros, costumam se enquadrar nessa categoria. }\end{array}$ \\
\hline Copreneurs & $\begin{array}{l}\text { Quando marido e mulher são sócios no negócio. A } \\
\text { fórmula funciona quando o casal se dá muito bem e } \\
\text { suas competências se complementam. Podem surgir } \\
\text { problemas caso confundam vida familiar e } \\
\text { profissional. }\end{array}$ \\
\hline Everypreneur & $\begin{array}{l}\text { Só conduz pequenos negócios. É guiado pelas } \\
\text { oportunidades e não se prende a uma área } \\
\text { específica. Para ele, vale a pena tentar qualquer tipo } \\
\text { de negócio, desde que seja lucrativo. }\end{array}$ \\
\hline Adventurepreneur & $\begin{array}{l}\text { É viciado em aventuras. Onde outros vêem riscos, } \\
\text { ele vê emoção. Embarca em negócios muito } \\
\text { diferentes e gosta de sentir a adrenalina gerada por } \\
\text { um novo desafio. Fica entediado quando a empresa } \\
\text { fica estável. }\end{array}$ \\
\hline Ecopreneur & $\begin{array}{l}\text { Perfil semelhante ao anterior. Mas, nesse caso, a } \\
\text { motivação é uma causa ambiental. }\end{array}$ \\
\hline Socialpreneur & $\begin{array}{l}\text { Envolve-se em projetos com causa, que tragam } \\
\text { benefícios para a sociedade. Não espera } \\
\text { remuneração: o que o motiva é o impacto que pode } \\
\text { provocar com suas iniciativas. }\end{array}$ \\
\hline Mompreneur / Dadpreneur & $\begin{array}{l}\text { É o pai ou a mãe com perfil empreendedor. Não } \\
\text { tem um negócio próprio, mas conduz a família de } \\
\text { forma empreendedora, tendo como principal } \\
\text { projeto de vida o sucesso da família. }\end{array}$ \\
\hline Teenpreneur & $\begin{array}{l}\text { Dono de negócios com menos de } 17 \text { anos, que } \\
\text { inicia projetos de pequeno porte, com ou sem fins }\end{array}$ \\
\hline
\end{tabular}




\begin{tabular}{|l|r|}
\hline & $\begin{array}{c}\text { lucrativos. É nessa fase que nascem muitos } \\
\text { empreendedores bem-sucedidos. }\end{array}$ \\
\hline Fempreneur & $\begin{array}{r}\text { Mulher empreendedora. Com forte presença na } \\
\text { cena nacional, caracteriza-se por buscar a } \\
\text { independência, aliada à flexibilidade para }\end{array}$ \\
& acomodar outras responsabilidades domésticas e \\
& familiares. \\
\hline
\end{tabular}

\begin{tabular}{|c|c|}
\hline Socialpreneur & $\begin{array}{l}\text { Abre um negócio e, quando este atinge um } \\
\text { determinado patamar de crescimento, vende e } \\
\text { recomeça do zero. Também atua na recuperação de } \\
\text { empresas em dificuldades. }\end{array}$ \\
\hline Technopreneur & $\begin{array}{l}\text { São empreendedores com forte formação técnica, } \\
\text { focados em inovação tecnológica, que atraem } \\
\text { investidores de risco. Estão com grande exposição } \\
\text { no Brasil atualmente. }\end{array}$ \\
\hline Elderpreneur & $\begin{array}{c}\text { São pessoas da terceira idade com grande } \\
\text { experiência, espírito vivaz e carreira executiva em } \\
\text { declínio. Ao se aposentarem, aproveitam seu } \\
\text { conhecimento, vivência e contatos para começar } \\
\text { uma carreira empreendedora. }\end{array}$ \\
\hline Etnopreneur & $\begin{array}{l}\text { Estabelecem negócios para atender minorias, } \\
\text { geralmente agrupadas por etnias, como judeus, } \\
\text { coreanos, ou brasileiros em Nova York. }\end{array}$ \\
\hline Intrapreneur & $\begin{array}{l}\text { São funcionários que trazem suas ideias e } \\
\text { iniciativas para agregar valor ao seu emprego, } \\
\text { favorecendo a si mesmo e à organização. }\end{array}$ \\
\hline Passionpreneur & $\begin{array}{l}\text { Aquele que transforma um hobby ou passatempo } \\
\text { em uma atividade empreendedora. Não está } \\
\text { interessado em ganhar muito dinheiro, e sim em } \\
\text { transformar sua paixão em fonte de renda. }\end{array}$ \\
\hline
\end{tabular}

Fonte: Adaptado de Hashimoto (2010, s.p.) 
Segundo Hashimoto (2013), são várias as modalidades de caracterização que moldam o perfil de um empreendedor e que de fato são encontradas mais de uma no mesmo indivíduo, como ser iniciante e se tornar empreendedor já na menor idade, ser incentivado por pai ou mãe que não são empreendedores, mas que projetam nos filhos esse espírito empreendedor, dentre outras.

\subsection{A influência do perfil do empreendedor na longevidade das empresas brasileiras}

Segundo Tales (2014), as características dos empreendimentos que se identificam com o perfil do empreendedor brasileiro são listadas em sete principais categorias: setor de atividade econômica; formalização; faturamento; inovação; uso da internet; tipo de cliente; e geração de empregos. Respeitando o estágio de desenvolvimento dos empreendimentos iniciais e estabelecidos, os especialistas identificam os fatores que influenciam o empreendimento no Brasil e os classificam por grau de importância da seguinte forma:

Para os empreendedores iniciantes o fator de maior impacto na manutenção de um negócio, com índice de $54 \%$, é o baixo acesso a recursos financeiros. Já para os empreendedores estabelecidos é a legislação e os impostos que tem uma representatividade de $57,2 \%$ e que sofre variação em diferentes regiões do país. Desse modo, o acesso à infraestrutura física; acesso ao mercado; normas culturais e sociais; infraestrutura comercial e profissional; apoio financeiro são fatores de influência positiva. Já a transferência de nova tecnologia; falta de capacitação; programas públicos e privados; políticas governamentais corroboram com os fatores de influências negativas. (TALES, 2014)

Segundo Gonçalves (2014), a Endeavor realizou uma pesquisa sobre os perfis empreendedores e constatou que "conhecer o próprio perfil ajuda a escolher o melhor negócio em que investir", o perfil empreendedor é um fator importante na longevidade do empreendimento, pois a pesquisa apontou que a população brasileira se divide em seis perfis empreendedores, sendo eles natos, meu jeito, situacionista, herdeiro, idealista ou em busca do milhão. Entenda cada perfil, a influência e a porcentagem no Brasil, sendo eles:

Natos: A motivação principal desse tipo de empreendedor é realizar seu sonho. Este tipo tem a tendência de ser empreendedor mesmo quando trabalha para outras pessoas. É o que mais aposta na atividade empreendedora para desenvolver o país e tem grande interesse em abrir um negócio nos próximos cinco anos, $12 \%$.

Meu jeito: Esse tipo de empreendedor quer fazer tudo do seu jeito e ser reconhecido por isso. Tem dificuldade de trabalhar em algo que não acredite e é fiel a suas crenças, ambições e valores. Em geral, tem pouca capacitação para empreender e concentra maior número de autônomos profissionais liberais, $14 \%$.

Situacionista: De alguma maneira, os empreendedores desse perfil foram levados a empreender por questões como uma oportunidade que apareceu ou grande insatisfação com o mercado atual. Em geral, são menos otimistas e tem mais aversão ao risco, $31 \%$.

Herdeiro: $\mathrm{O}$ empreendedor com esse perfil cresceu muito próximo a um modelo empreendedor e foi incentivado a seguir esse caminho. Alguns, literalmente herdam o negócio dos familiares. Experiências anteriores, tanto positivas quanto negativas, são a motivação principal, $7 \%$. 
Idealista: A motivação principal desse tipo de empreendedor é contribuir, fazer a sua parte. Ele busca contribuir para uma transformação social, ajudando a melhorar a vida de um grupo de pessoas, sem abrir mão de seus valores, $12 \%$.

Busca do Milhão: O maior foco desse empreendedor é o lucro e empreendedorismo é à sua maneira para alcançar fortuna. É ambicioso e ganancioso, 25\%. (GONÇALVES, 2014, p. 38-74).

Sobre a temática, Mello (2012) contribui ao afirmar que o conhecimento profissional é uma das características e peculiaridades dentro da área de atuação da empresa que interage com as tendências de mercado e respectivas implicações de clientes. Logo empreendedor é aquele que identifica novos negócios nos mercados de atuação e cria novos projetos que elevam a empresa a um patamar de competitividade.

Segundo Birley e Muzyka (2001), o fato de os empreendedores não serem todos iguais, possuírem características próprias e traços de personalidades específicas, faz com que o autoconhecimento de suas limitações e controle de si mesmo torne-se uma ampla fonte de força para o sucesso da empresa. Tendo em vista que uma das principais causas de problemas para a longevidade do empreendimento é o perfil do próprio empreendedor.

\subsection{Longevidade do empreendimento}

O tempo de vida de uma empresa é medido pelo período de sua constituição, atividade e encerramento. No Brasil o controle desse processo é feito pelo Instituto Brasileiro de Geografia e Estatística (IBGE) e Banco Nacional de Desenvolvimento Econômico e Social (BNDES). Segundo o SEBRAE (2013), com base nos dados da Secretária da Receita Federal (SRF), das empresas que iniciaram suas atividades em 2007 até 2010, o tempo médio de sobrevivência foi de dois anos de vida, superando as que iniciaram em anos anteriores, no âmbito nacional.

Segundo Bernhoeft e Martinez (2011) a longevidade de uma empresa irá depender da estabilidade econômica, do cenário empresarial competitivo, da crescente perspectiva de globalização e de como o empreendedor equilibrará todo este complicado processo. Os autores reforçam que a empresa é a somatória de vínculos entre sócios e familiares, onde as decisões devem ser tomadas com racionalidade, considerando-se o patrimônio, mas sem desconsiderar as variáveis emocionas que envolvem toda a história e origem da organização. Pois os valores e crenças fazem parte das características que compõe a empresa.

Administrar o patrimônio, as relações, o legado, os desejos, as ambições e as prioridades-individuais e coletiva-requerem, simultaneamente, complementariedade e visão de conjunto. [...] ser membro de uma família empresária implica em ter "bônus" e "ônus”. (BERNHOEFT; MARTINEZ, 2011, p. 116).

Não se deve deixar que os mitos influenciem o empreendimento, mas analisar com cautela e ater-se às necessidades da sociedade com projetos inovadores, ver nos problemas as oportunidades, pois o sucesso é baseado na satisfação de ter a solução do problema. O segredo do sucesso também está na capacidade de enxergar as oportunidades ao invés de apenas os obstáculos. Abaixo estão listados os principais mitos do empreendedorismo e a influência deles na formação do perfil empreendedor, bem como na duração e sucesso de uma empresa. Segundo Mendes (2012, p. 56-57) vistos no quadro 3: 
Quadro 3 - Os Mitos do Empreendedorismo

\begin{tabular}{|c|c|}
\hline O mito da grande idéia & $\begin{array}{l}\text { Esperar pela grande ideia pode ser uma péssima } \\
\text { ideia. }\end{array}$ \\
\hline O mito da genialidade & $\begin{array}{c}\text { Você pode até ser um gênio, mas não é garantia de } \\
\text { que vá se tornar um grande empreendedor. }\end{array}$ \\
\hline O mito da boa sorte & $\begin{array}{l}\text { Não existe negócio de sorte, não espere como se } \\
\text { fosse ganhar na loteria. }\end{array}$ \\
\hline O mito de capital inicial & $\begin{array}{l}\text { Sem capital também é possível começar um } \\
\text { empreendimento, vale ter em mente que seu } \\
\text { produto ou serviço pode agregar valor para a } \\
\text { sociedade. }\end{array}$ \\
\hline O mito que todos já nascem empreendedores & $\begin{array}{l}\text { Não são todos que nascem empreendedores é } \\
\text { impossível que isso aconteça. }\end{array}$ \\
\hline O mito dos apostadores & $\begin{array}{l}\text { Nem todos os empreendedores correm riscos } \\
\text { altíssimos, sem cálculo, afinal dinheiro não se joga } \\
\text { fora. }\end{array}$ \\
\hline O mito da independência & $\begin{array}{c}\text { É até verdade em num primeiro momento e durar } \\
\text { por um determinado período de tempo, mas, à } \\
\text { medida que o negócio decola, o empreendedor não } \\
\text { consegue sobreviver se não estiver cercado de } \\
\text { pessoas competentes para ajudá-lo a dividir as } \\
\text { tarefas de acordo com as habilidades especificas } \\
\text { para cada área. }\end{array}$ \\
\hline O mito do grande líder & $\begin{array}{c}\text { Não são todos os empreendedores de sucesso que } \\
\text { são ou serão grandes líderes. }\end{array}$ \\
\hline
\end{tabular}

Fonte: Adaptado de Mendes (2012, p. 56-57)

Estudiosos perseguem elucidar os fatores que determinam a eficiência e eficácia nos negócios e encontrar respostas para seus efeitos, a fim de alcançar meios para garantir o sucesso, ou de outra forma, a fim de evitar o fracasso da empresa:

$\mathrm{Na}$ Administração, a preocupação crescente com o sucesso e seu estudo nos últimos 10 (dez) anos parecem ter correlação com dois fatos: 1) o declínio de grandes empresas tradicionais e a ascensão de novas empresas líderes; 2) a difusão do conceito de "capital intelectual" (o valor de uma ideia) para compreender as grandes diferenças entre o valor de mercado e o respectivo valor contábil das empresas. 
(DUTRA; GIMENEZ, 2001, p. 170).

Em análise mais aprofundada, a longevidade de um empreendimento está associada à função de ajustar o ambiente interno às condições impostas pelo ambiente externo, na tentativa de adaptar a evolução da organização às pressões externas e internas, suas oportunidades e ameaças, forças e fraquezas, como sugere a análise SWOT (Strengths (Forças), Weknesses (Fraquezas), Opportunities (Oportunidades), Treats (Ameaças)), segundo Chiavenato (2005).

Para Collins e Porras (1995), as organizações que alcançam a longevidade apresentam capacidade e vontade de evoluir constantemente, sendo capazes de se adaptarem às mudanças do mercado, sem comprometer sua eficiência. Essa façanha está intrinsecamente ligada às habilidades para utilizar sua capacidade física e intelectual em prol de um objetivo central, seja ele social e/ou econômico.

A longevidade dos empreendimentos de grande, médio ou de pequeno porte não está necessariamente ligada ao ter-se iniciado com grandes recursos financeiros, pois alguns empreendedores iniciam do zero, mas transformam pequenas ideias em grandes negócios. Eles não só geram e distribuem riquezas, mas também contribuem para o bem-estar da sociedade. Vão além da criação de uma empresa, percebem nos problemas as oportunidades de um novo negócio, a exemplo de Henry Ford, Bill Gates, Steve Jobs e outros que não só prosperaram como transformaram muitos em prósperos também (MAXIMIANO, 2011).

Há três fatores que contribuem e/ou influenciam na longevidade de uma empresa, de acordo com Bernhoeft e Martinez (2011): família, patrimônio e empresa. De forma distinta, cada um desses fatores está relacionado com o tempo de sobrevivência da empresa no mercado. A longevidade da empresa é um processo de crescimento contínuo, tanto no mercado interno quanto no processo de internacionalização, sem abafar seus vínculos ou origens. Também influenciam a história, características distintas da empresa, valores, objetivo organizacional, perspectiva do negócio, além do desafio amplo de atingir gerações futuras dependentes do empreendimento.

1. Sistema família: Entende-se por valores da família um conjunto de princípios, crenças, ideologias, rituais e orientações que caracterizam a conduta dos familiares ao longo de sua história. Este conjunto deve ser transmitido às futuras gerações para que norteie sua forma de pensar e agir. (BERNHOEFT; MARTINEZ, 2011, p. 69)

2. Sistema patrimônio: A sociedade familiar, a partir da segunda geração, torna-se uma sociedade imposta, o que lhe dá características próprias, sem a figura de um "dono" e com vínculos que se criam pelo "capital”, por meio das participações herdadas. (BERNHOEFT; MARTINEZ, 2011, p. 80)

3. Sistema empresa: [...]. Em alguns casos, é possível observar decisões e investimentos de verticalização, o aproveitamento dos mercados já existentes e o uso da matéria-prima ou da sua capacidade produtiva. Sempre, porém, preservando suas atividades de origem. (BERNHOEFT; MARTINEZ, 2011, p. 93)

Na visão de Charan (2007) a responsabilidade começa quando o empreendedor determina e estabelece os objetivos certos, pois desta forma ao selecionar o conjunto certo de objetivos, definirá o rumo de decisões e ações que vêm a seguir e que podem influenciar os resultados produzidos. Estar comprometido com os resultados gera uma energia enorme na organização entre aqueles que trabalham nela, como fornecedores, 
por exemplo, pois se trata de estabelecer prioridades certas e buscar o resultado almejado.

Embora as prioridades devam ser absolutamente claras, muito específicas e, acima de tudo, exequíveis, isso não é suficiente. Uma vez estabelecidas, devem ser repetidas inúmeras vezes e acompanhadas para garantir que todos os envolvidos as entendam, aceitem e se orientem por elas, a fim de que a organização as execute e não se desvie do curso estabelecido. (CHARAN, 2007, p. 177).

Comprometimento com os resultados é um ponto de grande relevância para o bom desempenho do negócio. Buscar o aperfeiçoamento pessoal e profissional de forma contínua é tarefa de toda pessoa que busca o sucesso. Estabelecer prioridades precisas e importantes é o caminho para a concretização de objetivos (MELLO, 2012). Essas prioridades combinadas com o acompanhamento, atenção e recursos evitam que fatores importantes fiquem fora do foco do negócio.

Segundo Mello (2012), conhecer o negócio da empresa, assim como a área de atuação mais a capacidade de realização com experiências acumuladas e atualizadas denotam por parte do empreendedor conhecimentos técnicos adequados para a realização das suas atividades. Desta forma, flexibilizar e agilizar os processos internos e na cadeia de valor, procurando simplificar os procedimentos, melhorando o tempo de resposta para o cliente, é prioridade a ser seguida.

Ter iniciativa, autonomia, autoconfiança, otimismo, necessidade de realização. Trabalhar sozinho, ter perseverança e tenacidade. $\mathrm{O}$ fracasso é considerado um resultado como outro qualquer. $\mathrm{O}$ empreendedor aprende com resultados negativos, com os próprios erros. Tem grande energia. É um trabalhador incansável. Ele é capaz de se dedicar intensamente ao trabalho e sabe concentrar aos seus esforços para alcançar resultados. Saber fixar metas e alcançá-las. Luta contra padrões impostos. Diferenciar-se, tem a capacidade de ocupar um espaço não ocupado por outros mercados, descobrir nichos. Tem forte intuição. Tem sempre alto comprometimento e crê no que faz. Cria situações para obter feedback sobre o seu comportamento e sabe utilizar tais informações para o seu aprimoramento. Sabe buscar, utilizar e controlar recursos. É sonhador realista. Embora racional, usa também a parte direita do cérebro. É líder, cria um sistema próprio com seus empregados. É orientado para resultados, para o futuro, para o longo prazo. (DOLABELLA, 1999, p. 69).

Para Maximiano (2011) o empreendedor deve ser dotado das quatro competências específicas abaixo indicadas. Elas são fatores importantíssimos para a longevidade da empresa, uma vez que se faz necessário dominar ou ter um conhecimento mais aprimorado do negócio. Ou seja, se não sabe como fazer como será possível gerir? Entende-se que não basta somente idealizar, é necessário também planejar e administrar o empreendimento na íntegra.

O empreendedor deve ser capaz de gerir o negócio e definir objetivos relacionados ao início e crescimento da empresa, bem como ao desenvolvimento de novos produtos. Uma providencia simples, como a declaração da missão, ajuda a empresa a concentrar-se em um nicho, e isso é um fator crítico para a sobrevivência. O processo de planejamento exige que o empreendedor seja capaz de analisar a viabilidade de uma ideia ou oportunidade de negócio e sua implementação dentro das atividades da empresa - operações marketing, financeiras e assim por diante. O empreendedor deve ser capaz de preparar um plano de marketing, mostrando que conhece as necessidades e características do mercadoalvo. O sucesso de muitos negócios pequenos depende da capacidade de efetuar vendas e prestar os serviços que atendam às necessidades do nicho de mercado escolhido. O plano de marketing deve ser 
abrangente, prevendo atividades de promoção, matérias de apoio a vendas, propaganda e uma estratégia de relações públicas para fazer as ideias chegarem até o mercado-alvo. (MAXIMIANO, 2011, p.153).

Outro fator de importância na longevidade de uma empresa está na contabilidade, pois é um dos fatores que deve ser bem estruturado e controlado, pois nenhum empreendimento sobrevive a uma má gestão orçamentária ainda que haja disponibilidade do empreendedor em repor reservas com seu próprio capital. O que deve ser entendido e com muita clareza é que o capital da empresa é um e o capital próprio é outro. Os dois não devem ser confundidos, na hora de honrar os custos e despesas da empresa, segundo Maximiano (2011).

O sucesso e o fracasso de uma empresa estão muitos ligados à gestão do fluxo de caixa e dos processos da contabilidade. O empreendedor por esse motivo deve, no mínimo, conhecer o vocabulário da administração financeira, saber preparar orçamentos e lidar com a contabilidade, o controle do dinheiro e toda a parte fiscal. Estruturar e conduzir as operações do dia a dia também são atividades críticas para o sucesso de um empreendimento. O empreendedor deve ser capaz de reconhecer o impacto das operações sobre as finanças e de lidar eficazmente com as funções de compra, controle de estoques e planejamento das operações. Essas competências estão relacionadas com outras, como a capacidade de tomar decisões financeiras eficazes e de identificar as necessidades de capital do negócio. Outra competência correlata é a de negociar eficazmente com fornecedores a fim de conseguir as melhores condições para a empresa. (MAXIMIANO, 2011, p. 154).

Mello (2012) traz que a liderança ou como conduzir uma empresa é uma característica pessoal e, de maneira geral, leva em conta também a experiência e o repertório de vida e profissional e que cada pessoa desenvolve sua competência, o que de certa forma define sua marca pessoal. As competências necessárias para o bom desempenho do negócio são identificadas no dia a dia da empresa e no planejamento estratégico das atividades e suas prioridades para que aconteça o futuro desejado.

Competências compreendem o conjunto de características que uma pessoa dispõe e usa para realizar um determinado trabalho. São os conhecimentos, habilidades, experiências e valores que moldam atitudes e comportamentos na busca de resultados. A maestria no uso dessas ferramentas determina o crescimento profissional. Elas não são requeridas todas ao mesmo tempo, e algumas perdem alguma relevância à medida que se progride na carreira profissional. (MELLO, 2012, p. 192).

Ainda sobre esse ponto, Mello (2012) esclarece que algumas competências são essenciais para que os empreendedores possam aprimorar o desenvolvimento da empresa. $\mathrm{Na}$ construção diária dessas competências, o empreendedor deve procurar se desenvolver e amadurecer como pessoa e empresário, gerando energia e sinergia com todos os colaboradores, buscando melhores resultados para a empresa e por consequência o lucro para ambas as partes.

A comunicação é um ponto a ser considerado, pois se trata de uma necessidade de saber expressar suas ideias de forma convincente, persuasiva e clara para os diversos públicos com os quais se relaciona trará diferenças significativas em uma negociação. "Negociação é possuir capacidade de persuasão, envolvimento e interesse na solução de divergências e conflitos. Chega ao bom termo em situações difíceis e de conflitos, visando obtenção dos melhores resultados" (MELLO, 2012, p. 198).

Ainda segundo Mello (2012), outro fator importante é a visão estratégica, na qual o empreendedor 
demonstra possuir profundo conhecimento do seu negócio, das estratégias vigentes e diferenciais competitivos. O empreendedor deve apresentar capacidade de solucionar conflitos em sua área de atuação, possuir autocontrole e ser capaz de gerar soluções criativas nas situações de negociação, como faz-se referência no quadro 4.

Quadro 4 - Capacidades do empreendedor

\begin{tabular}{|c|c|}
\hline Assertividade & $\begin{array}{l}\text { Ter capacidade de analisar os fatos de maneira } \\
\text { objetiva, firme e com respeito, inclusive quando } \\
\text { exposto a conflitos, revelando equilíbrio e bom- } \\
\text { senso. }\end{array}$ \\
\hline Autodesenvolvimento & $\begin{array}{l}\text { Buscar o aperfeiçoamento pessoal de forma } \\
\text { continua. }\end{array}$ \\
\hline Comprometimento com os resultados & $\begin{array}{l}\text { Estar de fato comprometido com os resultados e } \\
\text { administrar os recursos da empresa como se fossem } \\
\text { próprios. Senso de urgência e atitude para fazer } \\
\text { acontecer. }\end{array}$ \\
\hline Conhecimento profissional & $\begin{array}{c}\text { Demonstrar conhecimento do negócio, métodos, } \\
\text { técnicas e procedimentos de sua área de } \\
\text { responsabilidade. }\end{array}$ \\
\hline Empreendedorismo & $\begin{array}{l}\text { Ter capacidade de transformar a visão em ação. } \\
\text { Atento às melhores práticas e melhorias. Ser pró- } \\
\text { ativo. }\end{array}$ \\
\hline Princípios e valores compartilhados & $\begin{array}{l}\text { Mostrar sensibilidade a questões éticas, morais, } \\
\text { sistema de valores e código sociais, assimilando e } \\
\text { disseminando os valores e as ações nele contidas. }\end{array}$ \\
\hline Foco no cliente & $\begin{array}{c}\text { Ser capaz de compreender e antecipar as } \\
\text { necessidades dos clientes internos e externos, tendo } \\
\text { comprometimento, senso de urgência e agilidade } \\
\text { para atuar de maneira prestativa, solidária e } \\
\text { responsável, gera confiabilidade. }\end{array}$ \\
\hline Iniciativa e tomada de decisão & $\begin{array}{l}\text { Possuir capacidade para identificação de } \\
\text { problemas. Analisa as circunstancias, busca dados, } \\
\text { subsídios e informações que sustentam a tomada de } \\
\text { decisões. Age com rapidez e qualidade nas }\end{array}$ \\
\hline
\end{tabular}




\begin{tabular}{|c|c|}
\hline & soluções e problemas. \\
\hline Liderança & $\begin{array}{l}\text { Ter capacidade de influenciar e motivar pessoas, } \\
\text { liderando através de exemplos e padrões claros em } \\
\text { busca dos objetivos e metas da organização. Integra } \\
\text { pessoas e processos. Forma e lidera equipes com } \\
\text { habilidade. Saber servir. E treinador. }\end{array}$ \\
\hline Negociação & $\begin{array}{l}\text { Possuir capacidade de persuasão, envolvimento e } \\
\text { interesse na solução de divergências e conflitos. } \\
\text { Chega ao bom termo em situação difíceis e de } \\
\text { conflitos, visando a obtenção dos melhores } \\
\text { resultados. }\end{array}$ \\
\hline Visão estratégica & $\begin{array}{l}\text { Diagnosticar a situação atual com realismo, } \\
\text { planejar e estruturar as ações necessárias para } \\
\text { atingir os objetivos, tendo visão de longo prazo, } \\
\text { pensamento sistêmico e foco em novas } \\
\text { oportunidades de negócio. Antecipar problemas } \\
\text { potenciais, desenvolver planos alternativos e ações } \\
\text { corretivas e preventivas. }\end{array}$ \\
\hline Trabalho em equipe & $\begin{array}{l}\text { Compartilhar, colaborar e desenvolver trabalhos } \\
\text { com outras pessoas de forma sinérgica e } \\
\text { harmônica, a fim de alcançar o melhor resultado } \\
\text { para a organização. }\end{array}$ \\
\hline Comunicação & $\begin{array}{l}\text { Ter habilidades e bom domínio das técnicas de } \\
\text { comunicação escrita e oral. Saber ouvir e ter } \\
\text { capacidade de disseminar a informação relevante } \\
\text { com clareza e eficácia. }\end{array}$ \\
\hline Inovação & $\begin{array}{l}\text { Ter visão inovadora e capacidade de transformá-la } \\
\text { em ação. Ser pró-ativo para promover mudanças } \\
\text { quânticas e incrementais com criatividade, } \\
\text { alinhando os objetivos estratégicos e valores da } \\
\text { organização. }\end{array}$ \\
\hline
\end{tabular}

São diferentes os fatores que determinam o sucesso de um empreendimento, entretanto, de forma 
constante, podem-se avaliar que uma pessoa dificilmente chegará ao sucesso se não tiver competências e características mínimas dos empreendedores que vivenciam o sucesso. Entre as características mais apontadas, a inovação ainda ocupa o primeiro lugar. Ela é a capacidade de correr riscos calculados, realização e autoconfiança (OLIVEIRA et al., 2012).

O empreendedor é alguém que sabe aonde quer chegar, não teme inovar, arriscar-se e assumir as responsabilidades decorrentes de suas escolhas. Marca que diferencia os empreendimentos longevos daqueles que não alcançam essa façanha. Está intrinsecamente ligada às habilidades para utilizar sua capacidade física e intelectual em prol de um objetivo central (HISHICH; PETER; SHEPHERD, 2009).

O que leva as empresas longevas a se perpetuarem por décadas é o processo dinâmico que se alterna, de geração em geração, na busca por constante renovação. Esta atitude não está restrita ao encontro de sucessores qualificados para gerenciar os sócios, mas sim nos processos de apoio, na busca por pessoas comprometidas, preparadas e conscientes dos diferentes desafios do porvir. Elas não limitam as possibilidades dentro de cada peculiaridade familiar, patrimônio, sociedade e empresa. Claro que cada caso detém uma atenção diferenciada, mesmo porque o país possui uma diversidade cultural vasta (BERNHOEFT; MARTINEZ, 2011).

\section{CARACTERIZAÇÃO DA ORGANIZAÇÃo}

\subsection{Dados Gerais}

A Multi Formato Distribuidora S/A, de nome fantasia Grupo Super Nosso é uma empresa de múltiplos negócios (varejo, atacado, autosserviço, distribuição, indústria). A empresa se destaca em dois ramos de negócios (varejo e distribuição) que a torna muito conhecida pelos nomes fantasias: Super Nosso Supermercados e Decminas Distribuidora. É reconhecida pelo excelente trabalho que realiza junto a fornecedores, compradores e cliente final.

Sua missão é contribuir para a satisfação e a qualidade de vida do cliente, oferecendo a melhor experiência de compra, através de lojas agradáveis, alta qualidade de atendimento, produtos e serviços, gerando confiança e resultados para acionistas, colaboradores, fornecedores e a sociedade em geral. Sua visão é ser reconhecida como a melhor solução em produtos e serviços diferenciados no segmento supermercadista da região metropolitana de Belo Horizonte. Seus valores são: Ética, Credibilidade, Responsabilidade, Inovação, Respeito, Prazer em Servir, Competitividade.

A razão social da empresa é Multi Formato Distribuidora S/A, o proprietário é Euler Fuad Nejm, a matriz da empresa está situada na Via Municipal Manoel Jacintho Coelho Junior, 901, bairro Tapera, BH/MG, cep 32150-245, seu ramo é o comércio atacadista, varejista e indústria de produtos alimentícios em geral, atualmente possui 7000 funcionários, o conjunto de empreendimentos que compõe a empresa é de 37 lojas físicas, 1 loja virtual, 2 centros de distribuição e 1 indústria [11].

\subsection{Histórico da empresa}

A empresa foi criada pelo imigrante e empreendedor libanês Fuad Elias Nejm em 1940, no bairro de Santa Tereza, Belo Horizonte MG, devido ao empenho do Sr. Fuad e também ao empreendedorismo do seu filho Euler Fuad Nejm, atual presidente da companhia, que evoluiu da seguinte forma: de um 
armazém, tornou-se atacado de balcão, retornou ao varejo de produtos alimentícios, tornou-se também autosserviço, distribuidora e indústria. Atua em Belo Horizonte e região metropolitana no ramo do comércio atacadista de produtos alimentícios em geral.

Seus principais produtos e serviços são os Produtos Gourmet [12], com preços atrativos para o consumidor, atendimento de excelência, SAC (Serviço de Atendimento ao Cliente), programa de fidelidades DOTZ (conhecimento de mais de 800 mil da base de clientes), eventos especiais, concursos culturais, sorteio de ingressos ou entradas exclusivas de camarotes de shows, circos, eventos e jogos de futebol, ofertas e brindes direcionados, e-mail marketing, entre outras. Elas se apresentam de acordo com a figura 1:

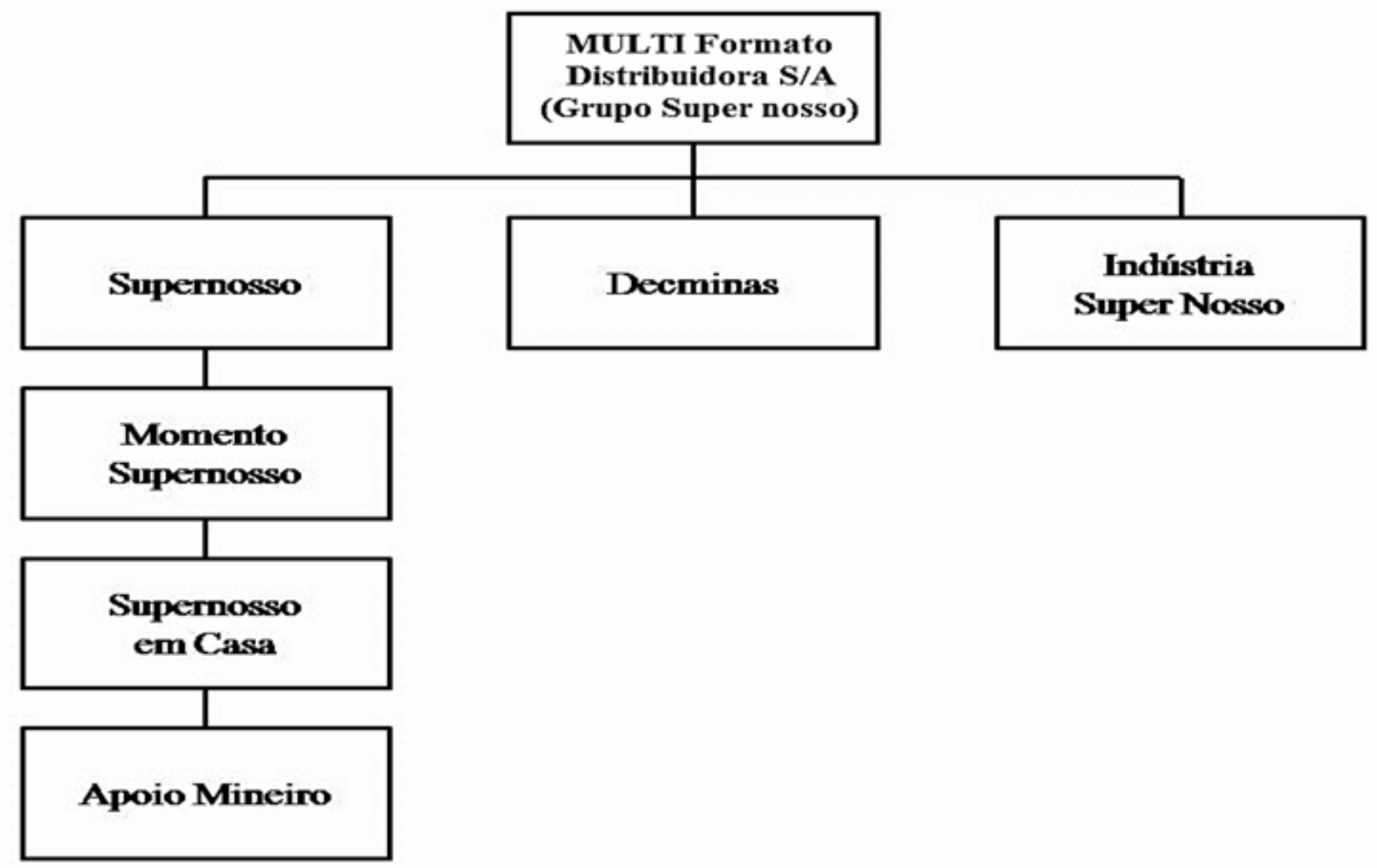

Figura 1 - Organograma do grupo empresarial. Fonte: Euler Fuad Nejm (2016)

Super Nosso: Segmento de lojas gourmet focado em atendimento, qualidade, variedade e serviços, 15 lojas; Momento Super Nosso: loja com conceito em conveniência, focado em praticidade e serviço, 8 lojas; Super Nosso em Casa: loja online, com mix e serviço diferenciado e entrega na região metropolitana de BH, 1 loja virtual; Apoio Mineiro: segmento de lojas focadas no atacado e varejo, que atendem desde o consumidor final, até padarias, restaurantes e pequenos comércios, 13 lojas; Decminas: Distribuidor de produtos exclusivos no mercado de Minas Gerais, 2 centros de distribuição; Indústria: Perecíveis (bovinos, suínos, aves e embutidos fatiados) - Padaria - Rotisseria - Empório, 1 indústria.

\subsection{Estrutura física}

Devido ao complexo da estrutura física da organização e de não ser o objeto da pesquisa qualquer um de 
seus estabelecimentos e sim seu proprietário fica declarada que a estrutura organizacional é de 37 lojas físicas, 1 loja virtual, 2 centros de distribuição e 1 indústria.

\subsection{Estrutura organizacional}

De acordo com Chiavenato (2001) a empresa deve ser organizada, mas para que isso ocorra deve ter claras as funções e a quem reportar, ponderando conflitos, no intuito de determinar atribuições e relações de cada um, o que é dividido em cinco etapas básicas: especialização, departamentalização, tarefa e cargo, distribuição e alocação de recursos necessários, coordenação e integração de esforços. Os organogramas são uma das formas de exemplificar essa organização dentro de uma empresa. A Multi Formato Distribuidora S/A, compõe seu organograma hierárquico, segundo Euler Fuad Nejm (2016) conforme o quadro 5:

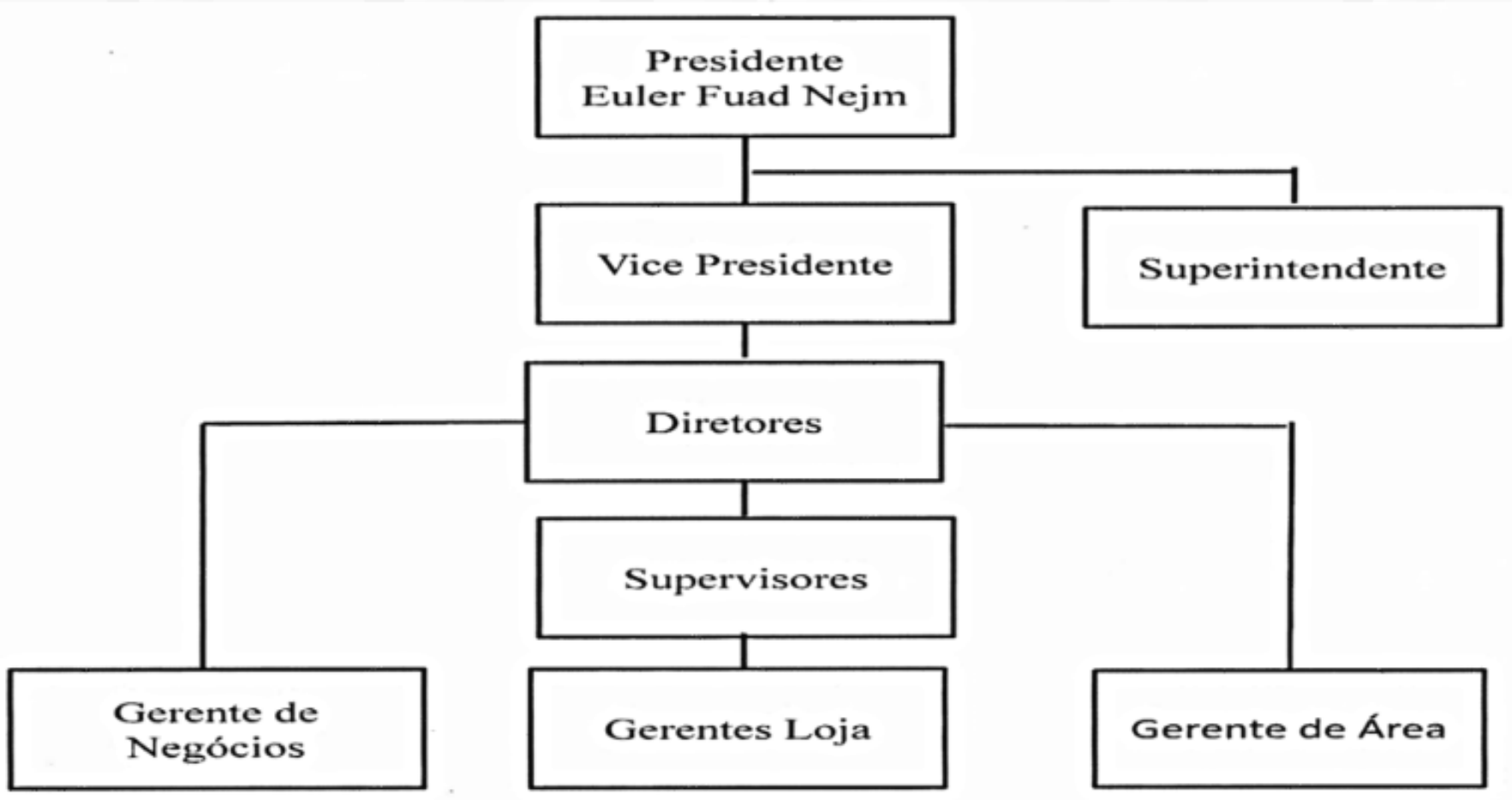

Quadro 5 - Organograma dos níveis hierárquicos Multi Formato Distribuidora S/A. Fonte: Euler Fuad Nejm (2016)

Ainda de acordo com Chiavenato (2001) o organograma define os órgãos que compõe a empresa, os canais de comunicação que interligam os cargos e a quem compreende cada um, de forma simples e direta, ou seja, a quem reportar ou a qual autoridade responder tanto na linha de comando horizontal como na vertical.

\subsection{Caracterização do empreendedor}

Euler Fuad Nejm, nascido em 22 de junho de 1961 em Belo Horizonte, formado em Administração de Empresas e Ciências Contábeis pela Pontifícia Universidade Católica de Minas Gerais (PUC Minas) e com especialização em Finanças pela Fundação Dom Cabral, cursos de aperfeiçoamento e tendências do varejo nas universidades de: Harvard (EUA) em 2011, Stanford (EUA) em 2012, Oxford (UK) em 2013, 
Sorbonne (França) em 2014 e University Club of Chicago (EUA) em 2015.

Iniciou no mundo dos negócios aos 8 anos de idade junto ao seu pai Fuad Elias Nejm, aos 15 anos foi emancipado e tornou-se sócio nos negócios, hoje aos 55 anos, pai de dois filhos, é proprietário e atual presidente da Multi Formato Distribuidora S/A, é vice-presidente da Associação Mineira de Supermercados (AMIS), conselheiro consultivo da Fundação CDL (Câmara de dirigentes lojistas) e sócio conselheiro da Rede Brasil de Supermercados.

\section{APRESENTAÇÃO E ANÁLISE DE DADOS}

Para realização desta pesquisa foi reunido aporte teórico, juntamente com um estudo de caso, cujo objeto da pesquisa foi o senhor Euler Fuad Nejm, proprietário e atual presidente da Multi Formato Distribuidora S/A, com sede à Via Municipal Manoel Jacinto Junior, 901, bairro Tapera, Contagem, MG. Com o intuito de responder a seguinte pergunta: o perfil do empreendedor influencia ou não na longevidade da empresa?

Foi realizada uma entrevista focal roteirizada com o senhor Euler Fuad Nejm no dia 10/10/2016 com início às $10 \mathrm{~h} 30$ no endereço da sede, onde participaram os pesquisadores deste trabalho. Em paralelo, foram abordados cinco colaboradores da empresa, vinculados ao Sr. Euler, contemplando diferentes níveis hierárquicos e de aproximação com o objeto de estudo. Os instrumentos de coleta de dados utilizados - roteiro e questionário - estão inclusos nos apêndices A e B deste relatório.

O reconhecimento desta identidade é consequência da combinação significativa de esforço, educação e experiência da parte do empreendedor cuja atividade não se restringe a uma interação técnica, mas envolve relações multiformes com a realidade empresarial de forma diferenciada e gradativamente construída, permitindo assim que tais relações possam levar os colaboradores a terem uma percepção de sua imagem. Tanto a identidade quanto a imagem compõem o perfil do empreendedor.

Conforme indicado por Dornelas (2007), se não houver envolvimento de todos os níveis hierárquicos da empresa na execução dos objetivos propostos, dificilmente haverá bons resultados. Desta forma, o confronto entre a coleta de dados e da aproximação com o senhor Euler Fuad Nejm, permitiu a observância desse envolvimento de forma que a percepção do próprio objeto oportunizou a compreensão da sua identidade e as respostas dos colaboradores permitiram verificar a projeção da sua imagem.

\subsection{Analise de dados na perspectiva do empreendedor}

Cada empreendedor tenciona buscar oportunidades e oferecer novos produtos, além de desejar que seu negócio seja viável. Sendo essa percepção de viabilidade tratada pelos estudiosos de auto eficácia empreendedora, ou seja, a convicção de que seu negócio pode ser executado com êxito. A auto eficácia aumenta a iniciativa e a persistência e, consequentemente melhora o desempenho. Essa predisposição percebida em fazer o melhor mais a viabilidade do negócio são ações que intensificam o agir empreendedor.

Visto que nem todos os empreendedores são iguais, ter autoconhecimento de suas limitações e controle de si mesmo, segundo Birley e Muzyka (2001) faz com que o empreendedor diante de um "não", veja como uma porta de oportunidade e não como uma barreira para seguir em frente. O que quando perguntado ao 
entrevistado se o "não" representa uma porta de oportunidade ou uma barreira para empreender, respondeu que, para ele, como empreendedor "o 'não' é uma porta de oportunidade, mas tem que respeitar, tentar filtrar a palavra "não”, pois muitas vezes ela seleciona as oportunidades, para mim é uma benção e muitas das vezes é uma oportunidade."

Corroborando com Hishich, Peters e Shepherd (2009), que além de identificar e avaliar a importância da oportunidade, o Sr. Euler classifica sua capacidade de "inovação" como característica muito importante ao empreendedor. Para ele "o sucesso de ontem não garante o sucesso de hoje e tão pouco de amanhã". Acrescenta ainda que "a rapidez das mudanças, das inovações e das adaptações são exponenciais, o empreendedor tem que ser muito rápido para selecionar e filtrar as oportunidades fortalecendo uma marca”. Este discurso está alinhado ao pensamento de Fillion (2000), que destaca a importância da iniciativa, visão, coragem, firmeza e capacidade de organização e direção.

O empreendedor deve ser criativo e prático desde o início. Habilidade e ousadia são características que distinguem o empreendedor segundo Maximiano (2011), questionado sobre como iniciou sua carreira empreendedora, o entrevistado relatou que começou a trabalhar muito jovem ( 8 anos), por influência de seu pai. No discurso abaixo é possível identificar várias características dos perfis de empreendedores brasileiros apontadas pela pesquisa da Endeavor (GONÇALVES, 2014) indicada no referencial, como as dos perfis nato, herdeiro e idealista.

"Às vezes eu batia na minha irmã e ele (pai) me prendia na loja, no armazém, como se fosse um castigo. [...] Ali eu não estava de castigo, eu estava era gostando e queria é corresponder àqueles desafios que ele me lançava. [...] fui me identificando, interessando, ou seja, comecei a cheirar armazém e participar daquela vida. [...] então acaba que a gente vai ambientando e acostumando; e o meu pai sempre me desafiando também e eu querendo corresponder a expectativa dele. Para falar a verdade até hoje eu tenho esse sentimento, ele morreu em 84, que dizer tem mais de 32 anos e eu ainda tenho o sentimento de que estou trabalhando para ele, a gente tem sempre que ter alguém como uma inspiração para ser cobrado senão fica muito solto, então eu me curvo ao meu pai e principalmente a Deus."

Como principais aliados no processo de aprendizado para empreender, são destacados pelo entrevistado as seguintes habilidades e competência: inovação, adaptabilidade, flexibilidade, agilidade, sabedoria para a tomada de decisões e liderança. Simultaneamente, justifica a seleção desses atributos por considerar o tripé recursos humanos, recursos financeiros e informações o principal entrave para o sucesso de um negócio.

"Você precisa de informações e conhecimento, você tem que ter conhecimento daquilo que você vai fazer, você precisa de dinheiro para investir [...] e recursos humanos [...] porque a gente depende de pessoas, depende de equipes [..] eu procuro ser fiel a quem é fiel comigo, dando oportunidade de atualização a essa equipe." (Afirma, o entrevistado).

Segundo Degen (2009), o importante ao iniciar um empreendimento é assegurar que vale a pena o esforço e os riscos que se vai incorrer. O entrevistado é enfático ao declarar que entre os fatores de risco de um negócio estão os recursos humanos, recursos financeiros e informações exaustivas sobre o ramo de negócio em que se pretende empreender, tendo o cuidado ao lidar com os recursos humanos entrelaçandoos no mesmo objetivo. 
Para ele, o empreendedor deve ser realista sobre os ganhos e desafios que o empreendimento trará para não criar expectativas maiores do que as que podem ser efetivamente alcançadas; destaca que é imprescindível conhecer o mercado para saber as reais margens de lucro que se pode obter, dentre outros cuidados.

Grandes ícones servem de inspiração para inúmeros empreendedores no Brasil e no mundo, o entrevistado referiu-se a seu pai, com grande admiração pela coragem, ousadia e espírito arguto; a Steve Jobs como o ícone principal e exemplo de empreendedor na atualidade; a Abílio Diniz como um exemplo no seu segmento; além de citar Silvio Santos, Antônio Ermírio de Morais como seus ídolos também.

Os ídolos impulsionam novos empreendedores que se espelham, evoluem e adquirem características, habilidades e/ou competências idênticas ou semelhantes a de seus ídolos. De certa forma a idealização contribui para moldar o tipo de perfil de um empreendedor, pois os são fontes de inspiração a qualquer empreendedor, independentemente de ser o de uma lojinha de bairro, oficina mecânica ou de uma multinacional. (DOLABELA, 2008)

Corroborando com Mendes (2012) para que as características empreendedoras são natas ou adquiridas, ficou evidente quando perguntado para o Sr. Euler Fuad Nejm qual seria a sua característica predominante, aquela que no ponto de vista dele, o tornou um empreendedor único, o mesmo respondeu que o empreendedor é um vendedor e sua função deve ser prioritariamente honesta e verdadeira. Na opinião dele um empreendedor precisa definir suas metas possíveis e ter determinação para alcançá-las. Destaca que o empreendedor não deve esmorecer e precisa ser incansável, já que as lutas serão árduas e diárias.

“Tem que ser determinado, ir ao trabalho, saber que vai matar dois leões por dia, amarrar o terceiro. Mas é isso mesmo, dificuldade sempre vai ter, um passo de cada vez. [...] Dificuldade sempre tem, não tem jeito, porque é só no dicionário que trabalho vem depois de sucesso, para ter sucesso tem que haver trabalho e vou falar que não é tudo maravilha.".

O entrevistado enfatizou que manter o foco é uma característica marcante do perfil empreendedor. Ele acredita que é necessário foco para saber dizer não quando algumas oportunidades batem à porta, pois se agarrar todas as oportunidades pode-se perder o foco do negócio, "você olha a sua missão e visão da empresa [..] é igual jogador de futebol, pode ser bom, mas tem que escolher uma área, uma posição."

Quando questionado sobre sua motivação, o maior desafio, a importância de se empreendedor no Brasil nos dias de hoje e qual a maior dificuldade encontrada por ele, o entrevistado se mostrou pouco motivado, apesar de ser um empreendedor já consolidado há anos no mercado local. Ele vê como um grande desafio montar equipes e reconhece que é importante o espírito empreendedor para o país crescer, gerar renda, criar empregos.

O entrevistado acredita que é importante empreender, mesmo com as altas cargas tributarias e burocracias brasileiras, o que é para ele uma das dificuldades no cenário atual, corroborando com Tales (2014) para quem as cargas tributarias e a legislação são os fatores que mais impactam no cenário do empreendedorismo nacional.

Ao mesmo tempo em que considera os recursos humanos e o trabalho em equipe fundamental ao 
exercício de empreender, o entrevistado destaca o papel solitário do empreendedor. Para explicar os desafios da gestão empreendedora ele constrói uma metáfora com o ato individual da direção automobilística e os vários e possíveis reveses. Esse comparativo ressalta as características de intensidade e aventura (no sentido de alto risco) que compõe o perfil do Sr. Euler, no ponto de vista do mesmo.

"Vamos imaginar que você está numa estrada a $130 \mathrm{~km} / \mathrm{h}$, céu claro, reta, mas depois escurece, pode vir uma chuva, uma curva, acredito que estamos exatamente nesse momento, estamos de noite, numa curva, fazendo uma analogia, uma curva a noite e chovendo, agora para nessa curva pra você ver. Vem uma carreta e te arrebenta, passa por cima, você tem é que diminuir, controlar o acelerador, se você acelerar na curva você vai bater, se você parar eles passam por cima... Então é controlar o acelerador, reduzir, mas não posso parar de crescer, crescer é a necessidade de sobrevivência, se falar já estou estabilizado, já tenho tantas lojas, não demora meses já estou superado, por isso tem que estar sempre inovando, procurando crescer."

Ao diferenciar empresário de empreendedor, o entrevistado destaca: "o empreendedor olha fora da caixa, vê outras oportunidades [...] o empresário vê só o negócio dele, já o empreendedor enxerga outras oportunidades, que preferencialmente estejam relacionadas ao seu negócio”. Essa percepção do empreendedor é confirmada por Maximiano (2011), que também faz a diferenciação entre inventor e empreendedor.

O entrevistado se auto define como um generalista do conhecimento, portanto, é consciente de que não domina todos os saberes. Para ele, o empreendedor ideal precisa ter percepção aguçada, entender que não cabe a ele as especificidades das áreas/diretorias que compõe a sua empresa e, portanto, a contratação de técnicos competentes é fundamental para auxiliar o negócio com os saberes múltiplos da administração.

O entrevistado Euler Fuad Nejm se identifica como um empreendedor corajoso, visionário, criativo, realizador, um pouco idealista e disciplinado, inovador, otimista, determinado, estrategista, responsável, perseverante/autoconfiante, intenso (trabalha com o coração), corajoso, íntegro, generalista e líder. Ele afirma não se deter facilmente, apesar dos reveses socioeconômicos que os empreendedores encontram na realidade brasileira. Num misto de coragem, determinação, conhecimento e ousadia, ele se mostra um entusiasta do processo empreendedor. Sua postura e discurso transparecem autoconfiança e ousadia.

Para Degen (2009), as oportunidades de negócio, baseadas em modismo são encontradas quando se procuram ideias originais, que podem encantar grande número de consumidores, mas esse encanto é passageiro e o empreendimento tem ciclo de vida rápido, requerendo do empreendedor grande perseverança para continuar. Da mesma forma, Hishich, Peter e Shepherd (2009) acreditam que a capacidade de saber aonde se quer chegar, bem como o perfil destemido e convicção pelas escolhas feitas constituem-se em marcas do perfil empreendedor. A junção de tais características, citadas acima determina ou não a longevidade das empresas.

O perfil do empreendedor tem impacto tanto positivo como também negativo segundo os teóricos, o que se comprovou quando perguntado ao entrevistado, se em sua opinião, o perfil do empreendedor impacta na longevidade da empresa e como, ou seja, de que maneira. Respondendo que sim, que se o empreendedor não tiver foco, visão do negócio, responsabilidade no que faz, é um apostador aumentando o risco de ganhar ou perder tudo, o que com certeza determina a longevidade da empresa e que não era o caso dele, pois "gosto de planejar para perpetuar a empresa". 
O grande sonho de milhões de brasileiros com idade maior de 18 anos é ser empreendedor, dono de seu próprio nariz, ter independência financeira, sonho este que é para muitos não ultrapassam de o primeiro ano de sobrevida. Como incentivo para àqueles que têm um sonho de empreender no Brasil, o entrevistado deixa os seguintes dizeres:

Buscar ser o melhor naquilo que se propuser a fazer, colocar o coração na frente para fazer, ter fé, determinação, honestidade; a soma desses valores é muito importante na vida pessoal e profissional da gente. Se gasta o mesmo tempo para fazer o errado e fazer o certo, então é ser determinado a fazer o certo, acredito ser o importante para o sucesso de qualquer coisa que se propuser.

Não existe uma característica única ou habilidade universal do tipo de empreendedor ideal, logo cada empreendedor é único em suas características e competências, união de conhecimentos e determinação de cada indivíduo é o que define seu tipo de perfil empreendedor e o sucesso o qual ele terá, corroborando com Degen (2009) e Maximiano (2011) que afirmam que o perfil do empreendedor é a combinação de características e competências reunidas em um indivíduo, umas mais que outras, em grau e intensidade diferentes e que variam de um indivíduo para outro.

\subsection{Analise de dados na perspectiva dos colaboradores}

Para caracterização dos colaboradores escolhidos para aplicação do questionário informa-se que $60 \%$ trabalham na empresa Multi Formato Distribuidora S/A há mais de 5 anos, podendo ser visto no gráfico 1 , o mesmo percentual (60\%) considera seu grau de aproximação com o objeto pesquisado restrito às questões profissionais também visto no gráfico 2. Já $40 \%$ afirma ter contato direto/próximo (20\% cada) com o objeto da pesquisa, o que significa acesso à sua rotina pessoal/familiar do mesmo, dentro do mesmo percentual (40\%) trabalham na empresa há 5 anos ou menos de 5 anos.

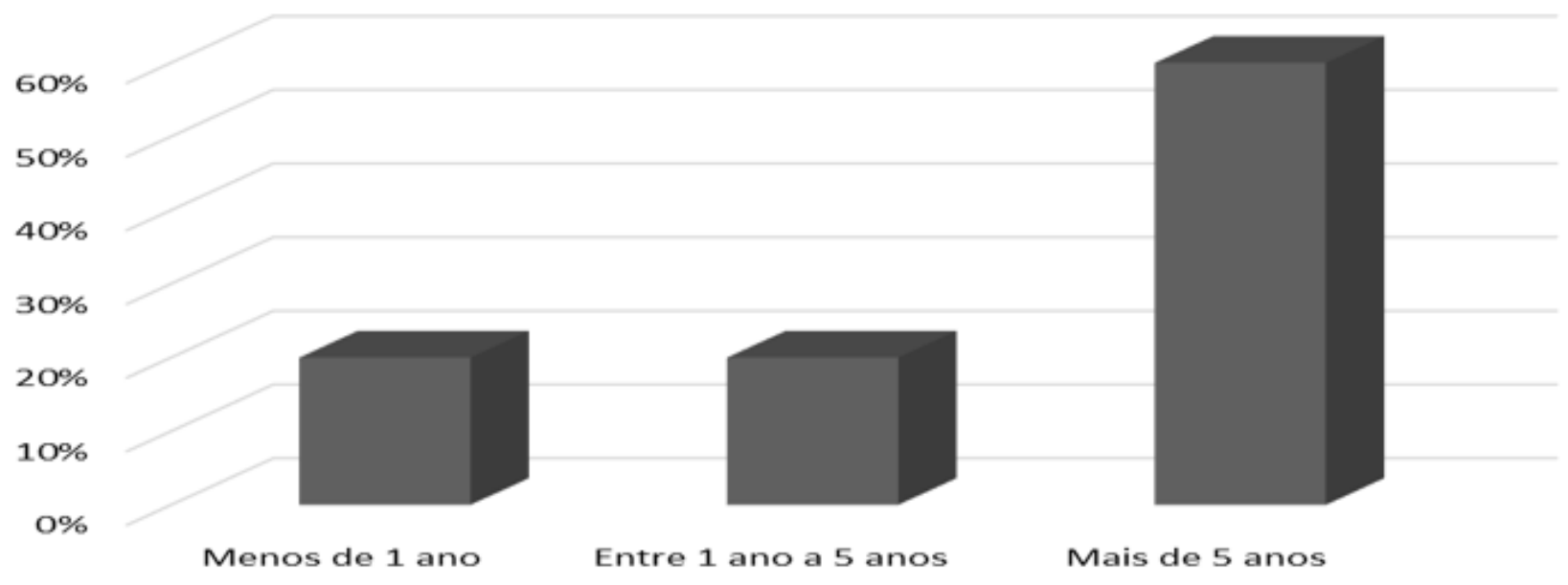

Gráfico 1 - Tempo de trabalho na empresa Multi Formato Distribuidora S/A. Fonte: Dados da pesquisa (2016) 


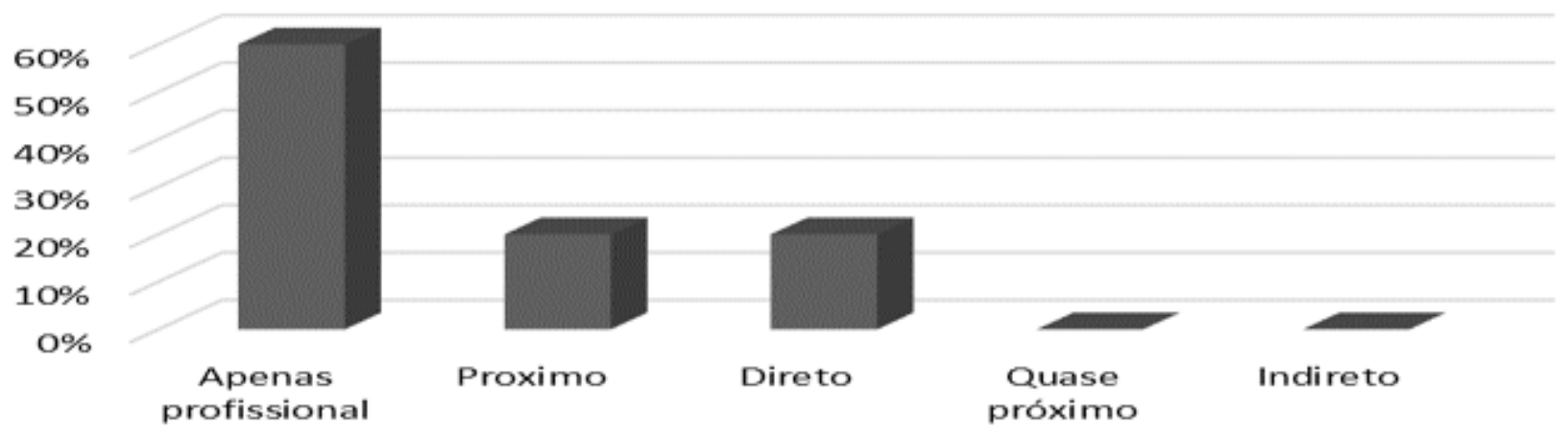

Gráfico 2 - Grau de proximidade com Euler. Fonte: Dados da pesquisa (2016)

80\% dos entrevistados o avaliam o senhor Euler como um líder acessível e o mesmo percentual também o consideram um empreendedor muito bom, resultado esse que é demonstrado nos gráficos 3 e 4 que seguem abaixo.

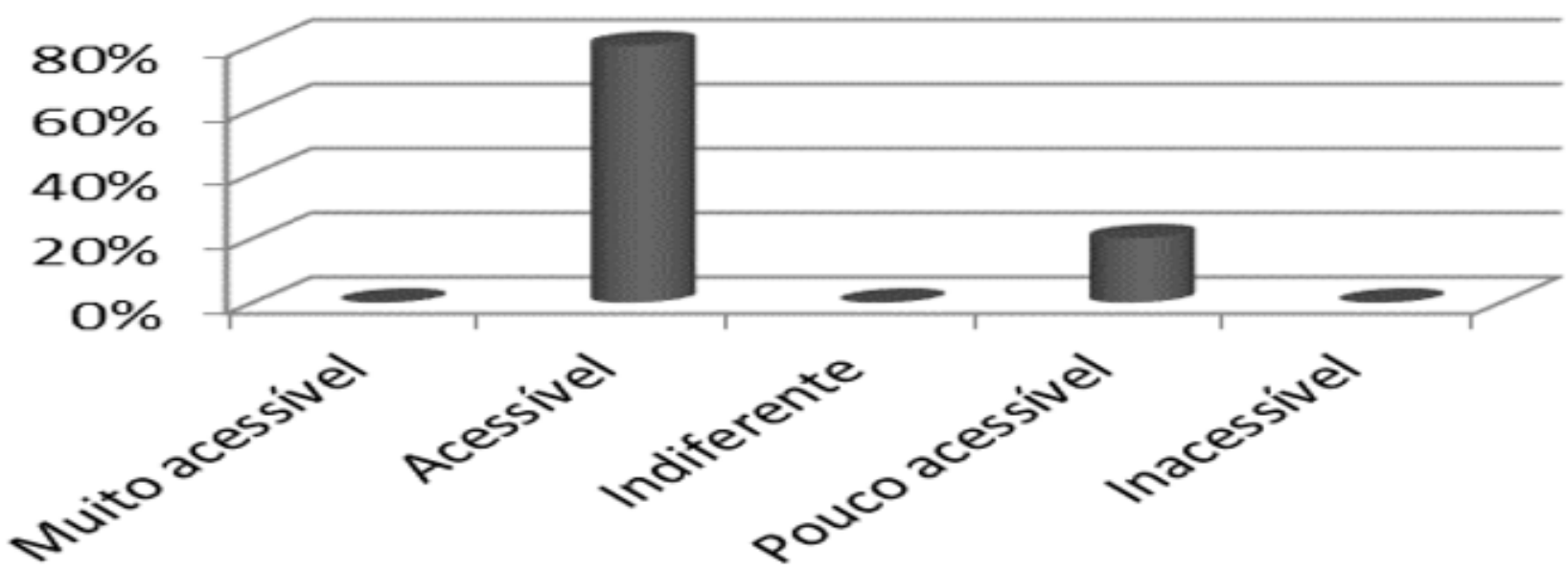

Gráfico 3 - Consideram o senhor Euler um líder acessível. Fonte: Dados da pesquisa (2016) 


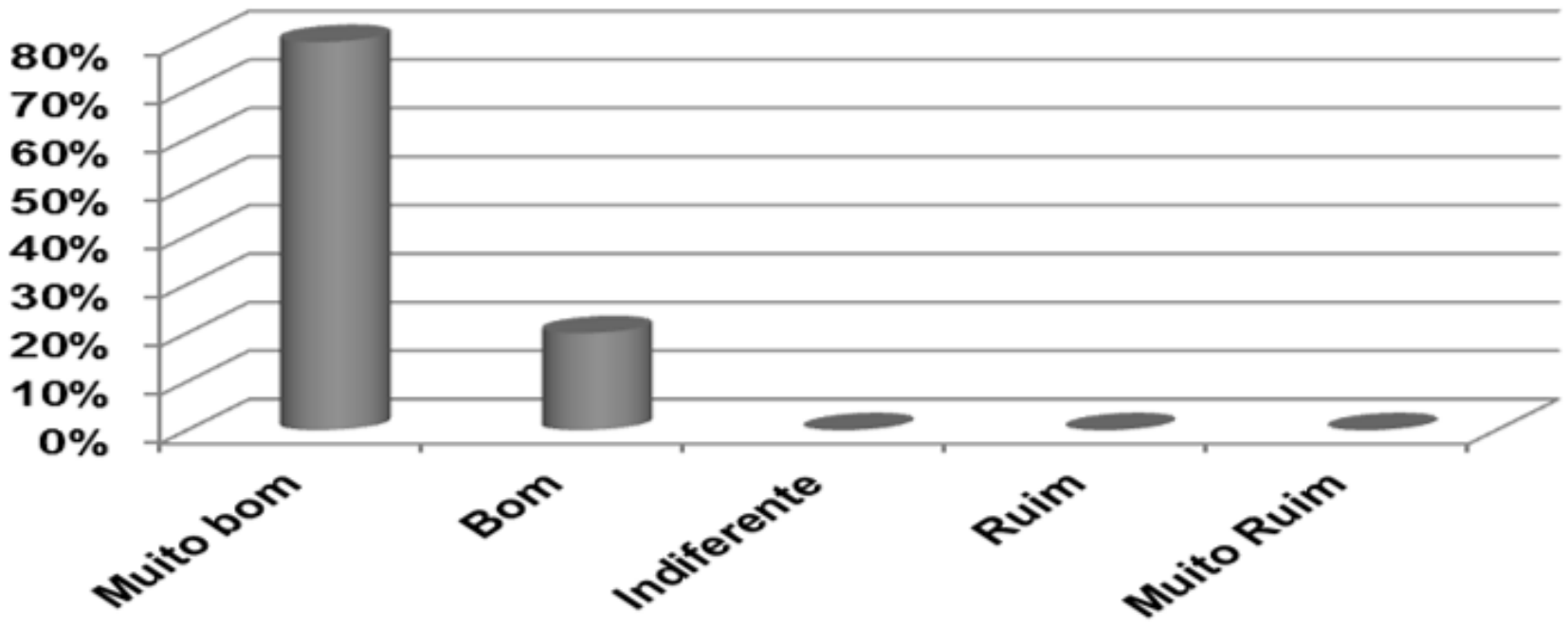

Gráfico 4 - Como avaliam Euler Fuad Nejm como empreendedor. Fonte: Dados da pesquisa (2016)

Questionados sobre o estilo de liderança do Sr. Euler Fuad Nejm, e como o mesmo pratica o esforço de envolvimento da equipe na construção do pilar de recursos humanos da empresa, $100 \%$ dos entrevistados afirmam estar satisfeitos com o estilo de gerenciamento dele e $80 \%$ desses respondentes afirmam que o fato de o considerarem um empreendedor de sucesso impacta nesta percepção do ser motivador que lidera a organização. O que pode ser contatado nos gráficos 5 e 6 .

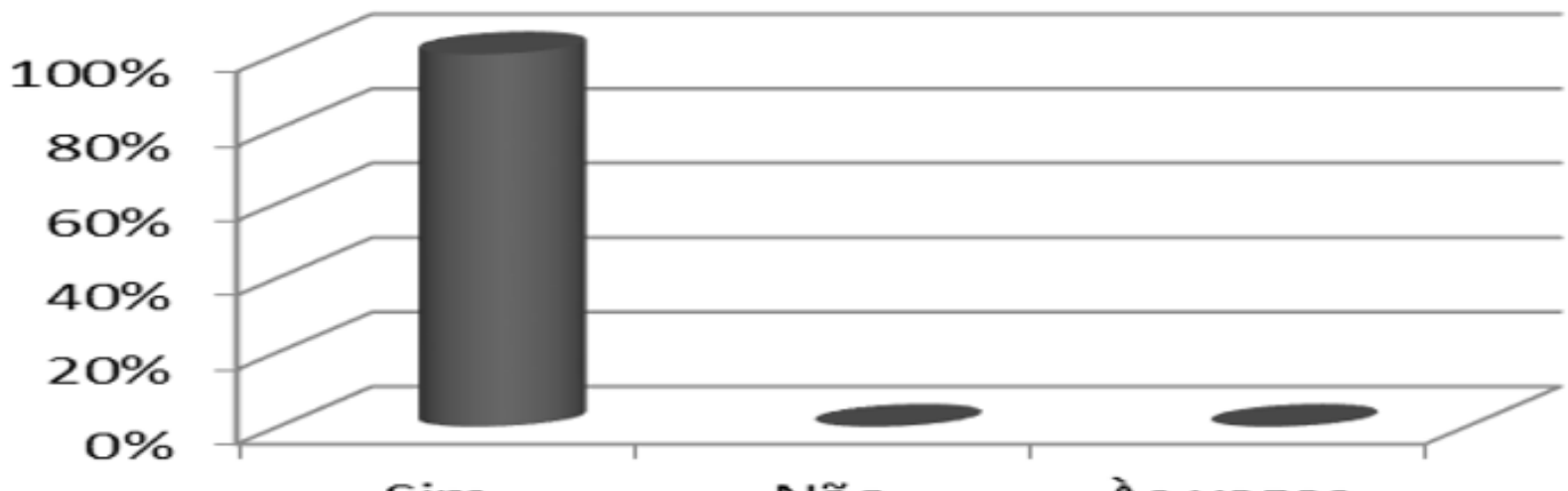

Gráfico 5 - Gosta da forma do gerenciamento/ estilo de liderança do sr. Euler. Fonte: Dados da pesquisa (2016) 


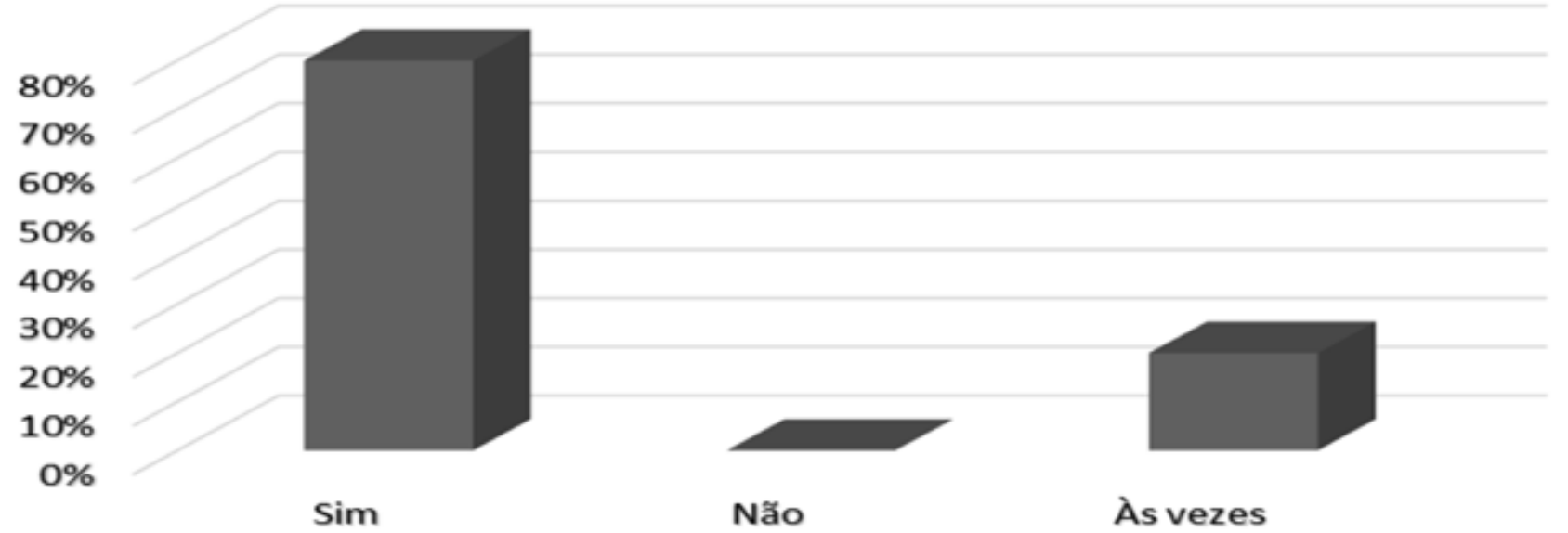

Gráfico 6 - Euler Fuad Nejm é inspirador do espírito empreendedor na organização. Fonte: dados da pesquisa (2016)

Apesar de seu próprio depoimento, onde destaca o importante papel do pai em sua formação empreendedora, os colaboradores entrevistados ao serem questionados sobre os fatores mais importantes no sucesso do Sr. Euler, creditam todo mérito exclusivamente ao seu próprio perfil e estilo gerencial. $\mathrm{O}$ que pode ser constatado no gráfico 7.

Não apenas o entrevistado, mas os seus colaboradores também identificam características empreendedoras marcantes no seu perfil. $100 \%$ dos respondentes afirmam que ele é um líder visionário, focado, estrategista, disciplinado e administrador, conforme apresentado no gráfico 8.

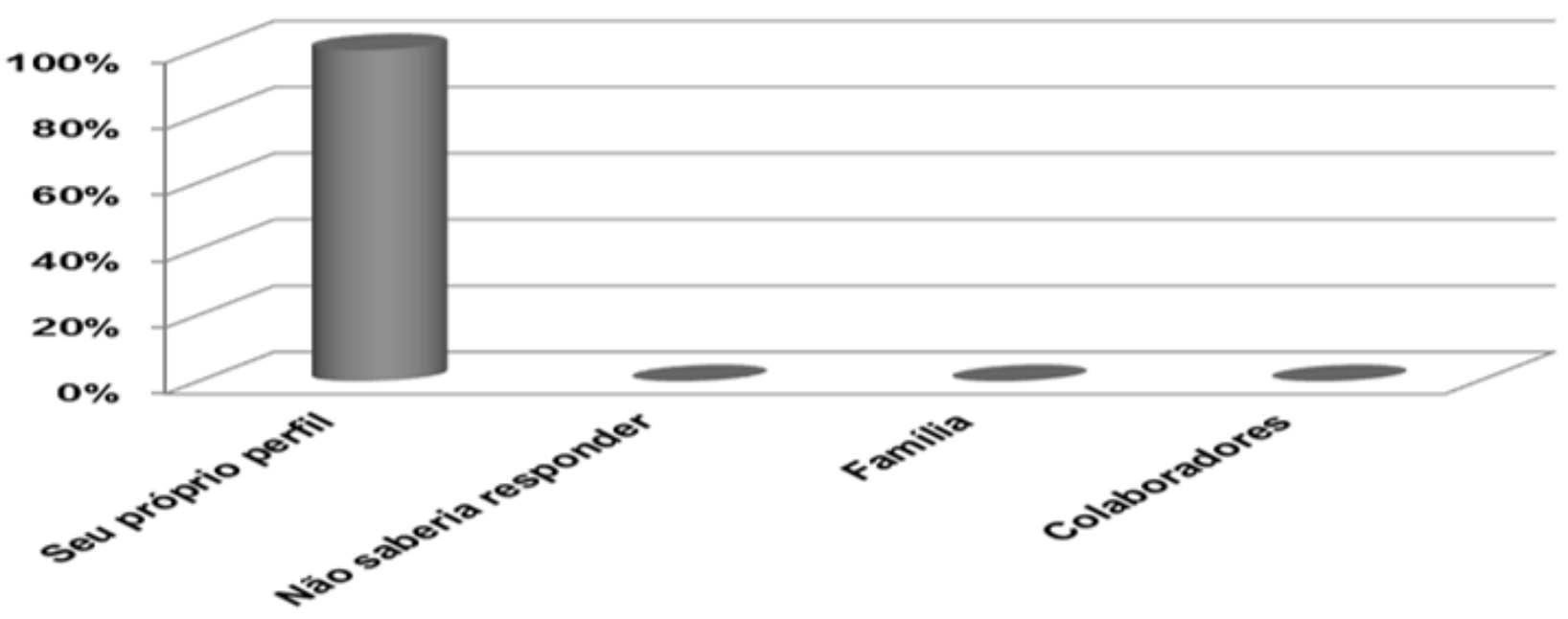

Gráfico 7 - Fatores mais importantes no sucesso do empreendedor na visão dos colaboradores. Fonte: Dados da pesquisa (2016) 


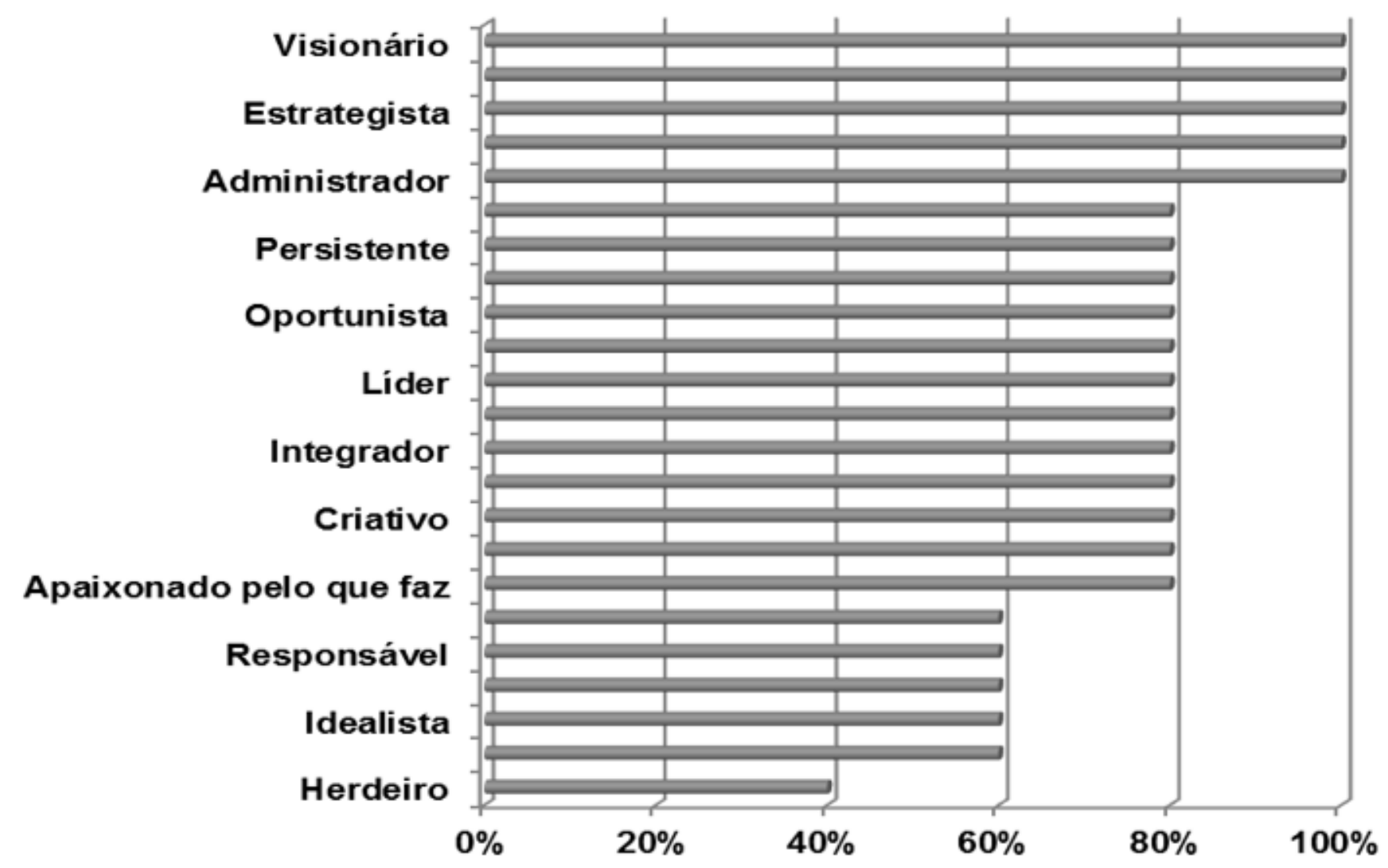

Gráfico 8 - Características empreendedoras do objeto de pesquisa no ponto de vista dos colaboradores. Fonte: Dados da pesquisa (2016)

Corroborando não só com teóricos, mas também com a análise dos colaboradores o que mais influência no tempo de vida da empresa é a visão de negócio, o espírito empreendedor, a liderança, determinação, foco e a paixão pelo que faz, presentes no perfil do Sr. Euler. A composição dessas características, somadas às habilidades e competências adquiridas ao longo do tempo, é o que faz com que a Multi Formato permaneça integra há tantos anos no mercado.

Conforme Bernhoeft e Martinez (2011) este é um caso resultante de uma empresa familiar onde há herdeiro e legado trabalhando em total harmonia, sem perder suas origens e raízes o que possibilitará essa empresa a se tornar centenária, pois a Multi Formato Distribuidora S/A já está no mercado há 76 anos.

\section{CONSIDERAÇÕES FINAIS}

Uma das principais causas na longevidade de uma empresa é a influência exercida pelo empreendedor, o que dependendo do tipo de perfil, e de como a organização é gerenciada, poderá perpetuar ou levar a extinção precoce da empresa, tendo em vista princípios de que um empreendedor não visa só o lucro momentâneo, mas também em deixar um legado para gerações futuras.

Observou-se várias características empreendedoras do sr. Euler Fuad Nejm, mas não se pode dizer que foram as únicas responsáveis pelo sucesso e longevidade da empresa Multi Formato Distribuidora S/A, também são responsáveis a capacidade de gestão, cultura familiar, equipe bem formada, entre outras, as 
responsáveis pelo sucesso e longevidade do empreendimento.

O empreendedor sempre espera atingir patamares cada vez mais altos, almeja crescer o suficiente para se tornar um ícone igual ou superior aos seus ídolos, muitas vezes um familiar no qual se inspira desde a infância - como relatado pelo Sr. Euler Fuad Nejm ou em alguém de projeção no mundo dos negócios ou do mercado de interesse. Mas não basta ter sonhos para se tornar um empreendedor exitoso é preciso desenvolver competências e habilidades para dominar a responsabilidade e o desafio de torná-los possíveis.

Embora sejam alguns os tipos de perfis próprios dos empreendedores de sucesso, e que esses perfis envolvem habilidades múltiplas, como a criatividade, a força de trabalho, o caráter agregador, a astúcia, dentre outros, não é qualquer pessoa que pode levar um empreendimento ao sucesso e à longevidade. É preciso também saber avaliar o contexto, analisar as oportunidades, desenvolver liderança além de possuir conhecimento ou capacidade técnica, administrativa e contábil.

Saber avaliar as oportunidades que lhes batem à porta e dizer não a essas oportunidades, quando necessário (perspicácia), é uma característica que poucos empreendedores possuem e, ao mesmo tempo por este motivo, correm riscos que podem reduzir a longevidade da empresa. Também compõem o perfil do empreendedor de sucesso e que mantém as empresas lucrativas por muitos anos no mercado, adjetivos como líder, inovador, íntegro, criativo, corajoso, visionário, realizador, idealista, disciplinado, otimista, determinado, estrategista, responsável, perseverante/autoconfiante.

Para confirmar as teorias reunidas a partir da revisão bibliográfica desenvolvida, o trabalho de campo foi feito levando-se em conta o perfil do empresário de sucesso Euler Fuad Nejm, proprietário da Multi Formato Distribuidora S/A, o qual, por sua formação, estrutura familiar, conhecimento, experiência e elevados padrões de excelência, desenvolveu o seu próprio capital social empreendedor. Observou-se com esta pesquisa que o objeto deste estudo de caso, empreendedor consolidado no mercado há mais de trinta anos, possui todos os adjetivos expostos no parágrafo anterior.

Certamente questões levantadas sobre os diferentes perfis de empreendedores já foram bastante discutidas nos âmbitos acadêmico e empresarial. Mas a questão a qual os pesquisadores deste trabalho almejavam se deter - a influência, ou não, do perfil do empreendedor Euler Fuad Nejm na longevidade da empresa Multi Formato Distribuidora S/A - foi respondida, tanto com o apoio da consulta bibliográfica, quanto pelo trabalho de campo. Ficou evidente que neste caso o perfil do empreendedor é de suma importância para o desenvolvimento da organização e influenciou positivamente para o seu sucesso e perpetuação da empresa no mercado.

O processo empreendedor passa por diversas fases, desde encontrar, avaliar e desenvolver oportunidades de um empreendimento que satisfaça o empreendedor em suas expectativas e o mercado. A junção dessas etapas, aliadas às características do empreendedor, foram cenários desse estudo, em que o referencial teórico se consolidou como suporte ao aprendizado e a metodologia aplicada forneceu os meios pelos quais o objetivo geral foi delimitado e concluído, através dos objetivos específicos. A entrevista focal foi elaborada através dos tópicos abordados no roteiro e sua aplicação, somada ao questionário de abordagem aos colaboradores, contribuíram para o confronto de todas as informações coletadas.

Um dos grandes desafios no mundo organizacional é o tempo de vida das empresas. Assim sendo, além 
dos fatores macroeconômicos, da dificultosa realidade Brasil no que se refere a leis, regras e pouco incentivo ao desenvolvimento de uma cultura empreendedora, observa-se que o perfil empreendedor é extremamente relevante na manutenção das organizações. Não basta ter boas ideias, ou almejar ser "patrão de si mesmo". O empreendedor bem-sucedido é a somatória de características individuais natas, formação construída e constante atualização.

Foi observado que o Sr. Euler conhece e avalia os negócios em que investe reconhecendo as práticas bemsucedidas. Também possui grande disposição para inovar, promover benchmarking [13] e replicar os processos considerados exitosos. Por primar pela constante adequação de seus negócios, o que demonstra flexibilidade e coerência, ele consegue expandir a permanência das empresas do grupo no mercado.

Todo negócio possui padrões estruturais e dinâmicas apropriadas que interagem com diversos negócios, com o ambiente organizacional, o meio ambiente e com a sociedade em que está inserida, diante desse conjunto de fatores e das regras determinadas, a identidade do empreendedor e sua imagem são constantes imprescindíveis para a garantia de sucesso.

Observou-se, que o Sr. Euler Fuad Nejm é um estrategista nato, pois compreende desde cedo que os negócios são sistemas abertos, autossustentáveis e que competem com outros negócios na obtenção de recursos e na comercialização de seus produtos ou serviços. Tal afirmativa está evidenciada quando o objeto afirma determinar seu objetivo, expõe com clareza seus valores, compreende o ambiente competitivo, avalia os recursos disponíveis e faz com que seu plano de negócios seja executado efetivamente.

Da mesma forma, os recursos básicos de que o empreendedor pode dispor como capital, equipamento, instalações, recursos humanos, capital intelectual, dentre outros, são necessários e agregam valor para o negócio, cabendo ao empreendedor integrar tais recursos para atingir seu objetivo. Para tal, faz-se necessária a liderança como uma habilidade a mais do empreendedor, ser líder não é apenas delegar tarefas, mas conduzir o negócio de tal maneira que todos colaborem para que seja tudo bem feito, outra característica bem evidenciada no sujeito desta pesquisa.

Pode-se considerar que ser visionário, motivador e dinâmico também são características fundamentais para o engajamento da equipe no propósito comum da organização e para que o empreendimento obtenha sucesso. Atribui-se amplamente tais características ao empreendedor Sr Euler corroborando assim para que sua empresa se consolide por tanto tempo no mercado.

Uma característica apontada pelo próprio Sr Euler é a de ser vendedor, tal habilidade usando sua experiência e seu conhecimento, extrapola os limites da empresa e abre novos caminhos, alavancando o negócio para o sucesso e novas frentes. Ressalta-se uma característica observada ao longo da construção desse trabalho e que é um adjetivo muito pertinente ao entrevistado, a astúcia, ou seja, uma inteligência diferenciada, popularmente denominada "olho vivo". Essa sagacidade nata dele foi desenvolvida ao longo dos anos, através de observações e interações.

Mas é imprescindível destacar que o Sr Euler Fuad Nejm também é extremamente perspicaz, possui indiscutível agudeza de espírito, é talentoso, humilde e gentil. Tais características observadas pela pesquisa/análise/conclusão, vêm modestamente acrescentar à lista dos renomados autores citados ao longo deste projeto, como fazendo parte do rol de adjetivos do perfil empreendedor contemporâneo bem- 
sucedido.

Examinados todos os fatos conclui-se que sim, o perfil do empreendedor tem grande influência na longevidade da empresa. Também o perfil do empreendedor Sr. Euler Fuad Nejm foi caracterizado 100\% como administrador, visionário, focado, estrategista e disciplinado, o que somadas às competências adquiridas, que o tipo de negócio em que investe exige, é receita do sucesso e da longevidade da empresa Multi Formato distribuidora S/A comprovando o que já predito pelos teóricos consultados nesse trabalho.

Conclui-se, ainda, que as características marcantes e irrelevantes observadas na maioria dos empreendedores, consideradas pelos autores como natas ou adquiridas, são, no caso do objeto dessa pesquisa, o Sr Euler Fuad Nejm, características bem acentuadas, de tal forma que compõem a sua identidade, podendo ser percebidas por seus colaboradores e, de maneira contundente, se refletem no sucesso e na longevidade da empresa Multi Formato Distribuidora S/A, da qual é proprietário.

Tendo em vista o acima exposto conclui-se que esta pesquisa correspondeu de forma satisfatória às expectativas de seus pesquisadores em responder à pergunta: $\mathrm{O}$ perfil do empreendedor influencia ou não na longevidade da empresa?

Ressalta-se que esse estudo não se aplica a generalização de sucesso ou longevidade de outras empresas do mesmo ramo ou segmento ou até mesmo a outros empreendedores, caso haja semelhança e o mesmo resultado, ocorre que será mera coincidência, uma vez que o estudo só foi objetivo ao proprietário da empresa acima mencionada.

\section{REFERÊNCIAS}

ANDRADE, Maria Margarida de. Introdução à metodologia do trabalho científico. 10 ed. São Paulo: Atlas, 2010.

BERGAMINI, Cecília Whitaker. Psicologia aplicada à administração de empresas: psicologia do comportamento organizacional. 3 ed. São Paulo: Atlas, 1982.

BERNHOEFT, Renato; MARTINEZ, Chris. Empresas brasileiras centenárias. Rio de Janeiro: Agir, 2011.

BIRLEY, Sue; MUZYKA, Daniel F. Dominando os desafios do empreendedor. São Paulo: Pearson, 2001.

BRITTO, Francisco; WEVER, Luiz. Empreendedores brasileiros: vivendo e aprendendo com grandes nomes. Rio de Janeiro: Campus, 2003.

CHARAN, Ran. Know-how: as 8 competências que separam os que fazem dos que não fazem. Rio de Janeiro: Elsevier, 2007.

CHIAVENATO, Idalberto. Empreendedorismo: dando asas ao espírito empreendedor. São Paulo: Saraiva, 2005. 
CHIAVENATO, Idalberto. Teoria Geral da Administração: Abordagens prescritivas e normativas da administração. 6. ed. Rio de Janeiro: Elsevier, 2001. Disponível em: $<$ https://books.google.com.br/books?id=2eiK0J$3 \mathrm{kNIC} \& p g=\mathrm{PA} 252 \& \mathrm{dq}=\mathrm{n} \% \mathrm{C} 3 \% \mathrm{ADvel}+\mathrm{hier} \% \mathrm{C} 3 \% \mathrm{~A} 1$ rquico+organ ograma+vertical\&hl=ptBR\&sa=X\&ved=0ahUKEwi6zsOV8uzPAhVJKyYKHWtxCb8Q6AEIMjA $\mathrm{B} \# \mathrm{v}=$ onepage $\& \mathrm{q}=\mathrm{n} \% \mathrm{C} 3 \% \mathrm{ADvel} \% 20 \mathrm{hier} \% \mathrm{C} 3 \% \mathrm{~A} 1$ rquico\%20orga nograma\%20vertical\&f=false $>$. Acesso em: 18 out. 2016.

COLLINS, James C.; PORRAS, Jerry I. Feitas para durar: práticas bem-sucedidas de empresas visionárias. São Paulo: Rocco, 1995.

DEGEN, Ronald Jean. O empreendedor: empreender como opção de carreira. São Paulo: Pearson, 2009. DOLABELA, Fernando. O segredo de Luísa. São Paulo: Cultura Editores Associados, 1999.

DOLABELA, Fernando. Oficina do empreendedor. 6. ed. São Paulo: Cultura, 2008.

DOLABELA, Fernando. Quero construir a minha história. Rio de Janeiro: Sextante, 2009.

DORNELAS, José Carlos Assis. Empreendedorismo: transformando ideias em negócios. 5. ed. Rio de Janeiro: Empreende LTC, 2014.

DORNELAS, José Carlos Assis. Empreendedorismo na prática: mitos e verdades do empreendedor de sucesso. Rio de Janeiro: Elsevier, 2007.

DRUCKER, Peter F. Inovação e espírito empreendedor: práticas e princípios. 4. ed. São Paulo: Pioneira, 2002.

DUTRA, Ivan de Souza. O perfil do empreendedor e a mortalidade de micro e pequenas empresas londrinenses. 2002. Dissertação (Mestrado) - Universidade Estadual de Londrina, Programa de PósGraduação em Administração, Londrina, 2002.

GIL, Antônio Carlos. Como elaborar projetos de pesquisa. 4. ed. São Paulo: Atlas, 2002.

GIL, Antônio Carlos. Métodos e técnicas de pesquisa social. 5. ed. São Paulo: Atlas, 1999.

GONÇALVES, Pamella. Diretora de pesquisa e mobilização da Endeavor. Os 6 tipos mais comuns de empreendedores no Brasil. Revista Exame, abri. 2014. Disponível em: <http://exame.abril.com.br/pme/noticias/os-6-tipos-de-empreendedores-mais-comuns-no-brasil>.Acesso: em 31 maio 2016.

GREATTI, Ligia. Perfis empreendedores: análise comparativa das trajetórias de sucesso e do fracasso empresarial no Município de Maringá. Maringá: [s.n.], 2003.

FILLION, Lois Jacques. Empreendedorismo: empreendedores e proprietários-gerentes de pequenos 
negócios. Revista de Administração, São Paulo, v. 34, n. 2, p. 5-28, abr./jun., 1999.

HASHIMOTO, Marcos. Qual seu perfil empreendedor. [S.1.]: Revistapegn, 2010. Disponível em: <http ://revistapegn.globo.com/Revista/Common/0,EMI174207-17141,00-QUAL+E+O+SEU+PERFIL+EMP REENDEDOR.html>. Acesso em: 31 maio 2016.

HASHIMOTO, Marcos. Que tipo de empreendedor é você. [S.1.]: Revistapegn, 2013. Disponível em: < http://revistapegn.globo.com/Colunistas/Marcos-Hashimoto/noticia/2013/09/que-tipo-de-empreendedor-evoce.html>. Acesso em: 01 jun. 2016.

HISHICH, Robert D.; PETERS, Michael P.; SHEPHERD, Dean A. Empreendedorismo. 7. ed. Porto Alegre: Boookman, 2009.

MARCONI, Marina de Andrade; LAKATOS, Eva Maria. Fundamentos de metodologia científica. 7. ed. São Paulo: Atlas, 2010.

MAXIMIANO, Antônio Cesar Amaru. Administração para empreendedores: fundamentos da criação e da gestão de novos negócios. 2. ed. São Paulo: Pearson, 2011.

MELLO, Joamel Bruno de; ORTEGA, Marlene. Práticas de gestão empresarial e alta performance baseada em pessoas. São Paulo: Nova cultura, 2012.

MENDES, Jerônimo. Empreendedorismo para jovens: ferramentas, exemplos reais e exercícios para alinhar a sua vocação com o seu projeto de vida. São Paulo: Atlas, 2012.

OLIVEIRA, José Roberto Cajaíba de. et al. Longevidade empresarial e Características Empreendedoras: Análise das MPE's da Microrregião de Teófilo Otoni/MG. Rio de Janeiro: [s.n.], 2012.

Serviço Brasileiro de Apoio às Micro e Pequenas Empresas - SEBRAE. Perfil necessário ao empreendedor. [S.1.]: SEBRAE, 2015. Disponível em: 〈http://www.sebrae.com.br/empreendedorismo>. Acesso em: 31 maio 2016.

Serviço Brasileiro de Apoio às Micro e Pequenas Empresas - SEBRAE. Sobrevivência das empresas no Brasil: Coleção de Estudos e pesquisas. [S.1.]: SEBRAE, 2013. Disponível em: <http://www.sebrae.com. br/Sebrae/Portal\%20Sebrae/Anexos/Sobrevivencia_das_empresas_no_Brasil=2013.pdf>. Acesso em: 13 jul. 2016.

SEVERINO, Antônio Joaquim. Metodologia do trabalho científico. 23. ed. São Paulo: Cortez, 2007.

TALES, Andreassi et al. Global Entrepreneurship Monitor: Empreendedorismo no Brasil. Curitiba: IBQP, 2014.

VERGARA, S. C. Projetos de pesquisa em administração. 7. ed. São Paulo: Atlas, 2006.

WAGNER, John A. Comportamento Organizacional: criando vantagem competitiva. 2. ed. São Paulo. 
Saraiva, 2009.

\section{APÊNDICE A - Roteiro da entrevista}

Os estudantes do $8^{\circ}$ período - turno manhã do curso de Administração da Faculdade de Ciências Sociais Aplicadas de Belo Horizonte - FACISABH. Composto pelos integrantes: Agnaldo Morais - Ângela Andrade - Gizele Rodrigues - Jovane Ferreira - Lucilene Carmo. Entrevista o empreendedor, empresário Euler Fuad Nejm, proprietário e atual presidente da Multi Formato Distribuidora S/A, na matriz da mesma, situada na Via Municipal Manoel Jacinto Coelho Júnior, 901, Bairro Tapera, Contagem - MG.

O objetivo desta entrevista é identificar o perfil empreendedor do entrevistado Euler Fuad Nejm. Sob autorização do mesmo a entrevista será gravada por meio de áudio e/ou vídeo e que posteriormente será transcrito na integra no artigo sob o título Empreendedorismo: o perfil do empreendedor e a longevidade da empresa. A entrevista é parte do estudo de caso da pesquisa e que confere aos estudantes como parte importante para o trabalho de conclusão de curso (TCC).

Roteiro de entrevista:

1) A palavra "não" tem um forte impacto na vida de um empreendedor, para o senhor o " não" é um uma porta de oportunidade ou uma barreira para seguir em frente?

2) Como o senhor avalia sua capacidade inovadora?

3) Desde muito jovem seu pai sempre incentivou a desenvolver seu lado empreendedor. Você acredita que a paixão pelo mundo dos negócios veio de seu pai?

4) Desde de novo que descobriu seu talento de empreendedor e pôs na pratica, aperfeiçoando com o passar do tempo. O que foi mais difícil nesse processo de aprendizado?

5) Quais são os seus ídolos empreendedores?

6) Algumas características empreendedoras são natas, outras você adquiriu com o tempo através de estudos e da própria vivência. Para você qual é a característica predominante que lhe tornou um empreendedor único?

7) Qual a sua característica mais marcante?

8) Hoje, o que te motiva?

9) Qual é o seu maior desafio?

10) Para você qual é a importância de se empreender no Brasil e qual é a maior dificuldade?

11) Qual seu diferencial que fez e que faz com que a Multi Formato Distribuidora S/A perpetue por tantos anos no mercado? 
12) Em sua opinião qual é o perfil ideal de um empreendedor?

13) Se tivesse que o qualificas como empreendedor, como seria?

14) Vamos listar várias características que os teóricos apontam como sendo do perfil do empreendedor. A medida que falarmos cada característica, gostaríamos que se avaliasse. Quanto de cada uma dessas características faze parte do seu jeito de ser. Indique-nos se MUITO/NADA/UM POUCO.

\begin{tabular}{|c|c|c|c|c|c|}
\hline & Sim & Não & Muito & Nada & Mais ou menos \\
\hline \multicolumn{6}{|l|}{ Aventureiro } \\
\hline \multicolumn{6}{|l|}{ Idealista } \\
\hline \multicolumn{6}{|l|}{ Disciplinado } \\
\hline \multicolumn{6}{|l|}{ Responsável } \\
\hline \multicolumn{6}{|l|}{ Persistente } \\
\hline \multicolumn{6}{|l|}{ Focado } \\
\hline \multicolumn{6}{|l|}{ Líder } \\
\hline \multicolumn{6}{|l|}{ Otimista } \\
\hline \multicolumn{6}{|l|}{ Integro } \\
\hline \multicolumn{6}{|l|}{ Promotor } \\
\hline \multicolumn{6}{|l|}{ Situacionista } \\
\hline \multicolumn{6}{|l|}{$\begin{array}{l}\text { Apaixonado } \\
\text { pelo que faz }\end{array}$} \\
\hline \multicolumn{6}{|l|}{ Criativo } \\
\hline \multicolumn{6}{|l|}{ Realizador } \\
\hline \multicolumn{6}{|l|}{ Autoconfiante } \\
\hline \multicolumn{6}{|l|}{ Integrador } \\
\hline \multicolumn{6}{|l|}{ Visionário } \\
\hline \multicolumn{6}{|l|}{ Inovador } \\
\hline \multicolumn{6}{|l|}{ Nato } \\
\hline \multicolumn{6}{|l|}{ Herdeiro } \\
\hline \multicolumn{6}{|l|}{ Administrador } \\
\hline \multicolumn{6}{|l|}{ Estrategista } \\
\hline Oportunista & & & & & \\
\hline
\end{tabular}

15) Em sua opinião, o perfil do empreendedor impacta na longevidade da empresa? Se sim, como? 
16) Se sim, este é o seu caso?

17) $\mathrm{O}$ que você diria aquele que tem um sonho de ser empreendedor neste Brasil onde os impostos superam qualquer expectativa de se manter no mercado por mais de 1 ano?

\section{APÊNDICE B - Questionário aplicado a cinco funcionários da Multi Formato Distribuidora S/A}

O questionário tem a finalidade de caracterizar o perfil empreendedor do senhor Euler Fuad Nejm, proprietário e presidente da Multi Formato Distribuidora S/A. O questionário foi aplicado como formulário a cinco funcionários da empresa, mais próximos do senhor Euler Fuad Nejm, afim de fazer um comparativo com a entrevista e o referencial teórico.

1) Há quanto tempo trabalha na empresa?

() Menos de 1 ano

() Entre 1 ano a 5 anos

() Mais e 5 anos

2)Qual o grau de proximidade com o sr. Euler?

() Apenas profissional

() Próximo

() Direto

() Quase próximo

() Indireto

3) A acessibilidade ao sr. Euler é?

() Muito acessível

() Acessível

() Indiferente

() Pouco acessível

() Inacessível

4) Como você avalia o senhor Euler F. Nejm como empreendedor?

() Muito bom

() Bom

() Indiferente

() Ruim

() Muito Ruim

5) Gosta da forma que seu trabalho é liderado/ gerenciado pelo sr. Euler?

() $\mathrm{Sim}$

() Não

() Às vezes

6) O senhor Euler é motivador do espírito empreendedor na organização?

() $\mathrm{Sim}$

() Não 
() Às vezes

7) Você diria que o fator mais importante do sucesso do senhor Euler foi:

() Família

() Colaboradores

() Si próprio

() Não saberia responder

8) Quais são as características que identificam o senhor Euler na sua opinião? E com que intensidade?

\begin{tabular}{|c|c|c|c|c|c|}
\hline & Sim & Não & Muito & Nada & Mais ou menos \\
\hline \multicolumn{6}{|l|}{ Aventureiro } \\
\hline \multicolumn{6}{|l|}{ Idealista } \\
\hline \multicolumn{6}{|l|}{ Disciplinado } \\
\hline \multicolumn{6}{|l|}{ Responsável } \\
\hline \multicolumn{6}{|l|}{ Persistente } \\
\hline \multicolumn{6}{|l|}{ Focado } \\
\hline \multicolumn{6}{|l|}{ Líder } \\
\hline \multicolumn{6}{|l|}{ Otimista } \\
\hline \multicolumn{6}{|l|}{ Integro } \\
\hline \multicolumn{6}{|l|}{ Promotor } \\
\hline \multicolumn{6}{|l|}{ Situacionista } \\
\hline \multicolumn{6}{|c|}{ Apaixonado pelo que faz } \\
\hline \multicolumn{6}{|l|}{ Criativo } \\
\hline \multicolumn{6}{|l|}{ Realizador } \\
\hline \multicolumn{6}{|l|}{ Autoconfiante } \\
\hline \multicolumn{6}{|l|}{ Integrador } \\
\hline \multicolumn{6}{|l|}{ Visionário } \\
\hline \multicolumn{6}{|l|}{ Inovador } \\
\hline \multicolumn{6}{|l|}{ Nato } \\
\hline \multicolumn{6}{|l|}{ Herdeiro } \\
\hline \multicolumn{6}{|l|}{ Administrador } \\
\hline \multicolumn{6}{|l|}{ Estrategista } \\
\hline Oportunista & & & & & \\
\hline
\end{tabular}


9) Quais fatores, no seu ponto de vista, são responsáveis pelo tempo de vida da Multi Formato Distribuidora S/A?

10) Você acredita que o perfil de gestor do Sr. Euler influencia essa longevidade da empresa? Se sim, como?

\section{ANEXO A - Endereço filiais}

Av. Mario Werneck, 2.641, Buritis, BH/MG, cep 30.573-180

Rua Conde Dolabela, 1.527, Várzea, Lagoa santa/MG cep 33.400-000

Rua Gonçalves dias, 603, Funcionários, BH/MG, cep 30.140-091

Av. Brigadeiro Eduardo Gomes, 1.461, nossa sra. Da glória, BH/MG, cep 30.870-100

Av. Portugal 2481, Santa Amélia, BH/MG, cep 31.555-000

Av. Afonso Pena, 3.328, Cruzeiro, BH/MG, cep 30.130-009

Rua André Cavalcante, 237, Gutierrez, BH/MG, cep 30.441-025

Rua Gonçalves Dias, 1.979, Lourdes, BH/MG, cep 30.140-092

Av. Heráclito Mourão de Miranda, 1.700, Castelo/, BH/MG, cep 31.330-270

Av. Guaicui, 355, Coração de Jesus, BH/MG, cep 30.380-342

Rodovia MG 30, loja 18, Vale do Sereno, Nova Lima/MG, cep 34.000-000

Av. Vereador Joaquim Costa, 1.820, galpão 1, Campina verde, Contagem/MG, cep 32.150-240

Av. Silviano Brandão,3001, Horto, BH/MG, cep 31.015-434

Rua dr. Antônio Eustáquio Piazza, 2.725, Tirol, BH/MG, cep 30.662-050

Av. Cristiano Machado, 10.768, Floramar, BH/MG, cep 31.765-000

Av. Vereador João de Oliveira Michele, $\mathrm{n}^{\circ}$ 101, loja a p.seguro/Ribeirão das Neves, cep 33.863-005

Rodovia br 356, 450, sion, BH/MG, cep 30.390-003

Av. Cristiano Machado, 1794, loja 22,23 e 24- Cidade Nova/ BH, cep 31.170-800

Rua Romualdo Lopes Cançado, 125, loja 101 a 106- Castelo/ BH, cep 30.840-460 
Av. Cristiano Machado, 10752, loja a- Jardim Guanabara/ BH, cep 31.742-278

Av. Engenheiro Darcy Nogueira do Pinho, 3.201, galpão 3, Vila Cristina, Betim/MG, cep 32.675-515

Av. Amazonas, 1.464, Barro Preto, Belo Horizonte/MG, cep 30.180-003

Rua Mármore, 641, Santa Tereza, BH/MG, cep 31.010-220

Av. Severino Ballesteros Rodrigues, 850, loja 3007, Ressaca, Contagem/MG, cep 32.110-005

Rua Ceará, 1118, Funcionários, Belo Horizonte/MG - 30.150-311

Rua Paracatu, 747, Barro Preto, Belo Horizonte/MG, cep 30.180-090

Rua Felipe dos Santos, 587, Lourdes, Belo Horizonte/MG, cep 30.180-160

Rua dos Guajajaras, 843, Centro, Belo Horizonte/MG, cep 30.180-100

Praça Nova York, 78, loja 1, Sion, Belo Horizonte/MG. Cep 30.115.550

Rua Juiz Costa Val, 434, Santa Efigênia, Belo Horizonte/MG, cep 30.240-350

Av. Raja Gabaglia, 2.271, São Bento, Belo Horizonte/MG, cep 30.350-453

Av. Celso Porfirio Machado, 51, Belvedere, Belo Horizonte/MG, cep 30.320-400

Rua Rio Grande do Norte, 1.615, Funcionários, Belo Horizonte/MG, cep 30.130-131

Av. Edmeia Mattos Lazzarotti, 4455, Nossa Sra. Das Graças, Betim/MG, cep 32.604-745

Via expressa de Contagem,11854- Bernardo Monteiro, Contagem/MG, cep 32.070-005

Av. Silva Lobo, 900- Nova Suíça, BH/MG, cep 30.421-198

Rod. Anel Rodoviário Celso Mello Azevedo,17850, Sumaré, BH/MG, cep 31.250-175

Av. Vereador João de oliveira Michete,101, Porto Seguro, Ribeirão das Neves/MG, cep 33.863-005

Av. José Cândido da Silveira, 2996- Bairro Ana Lúcia, Sabará/MG, cep 34.710-138

Av. Prefeito Alberto Moura, 1260, Distrito Industrial, Sete Lagoas/MG, cep 35.702-383

Rua José Tofani, 35, São João Batista, Santa Luzia/MG, cep 33.030-005

Av. João Daher, 787, Centro, Lagoa Santa/MG, cep 33.400-000 
Revista Científica Multidisciplinar Núcleo do Conhecimento - RC: 11071 - ISSN: 2448-0959

https://www.nucleodoconhecimento.com.br/administracao/empreendedorismo

Av.Vereador Joaquim Costa, 1.820, galpão 2, Campina Verde, Contagem/MG, cep 32.150-240

ANEXO B - Foto dos autores com Euler Fuad Nejm 


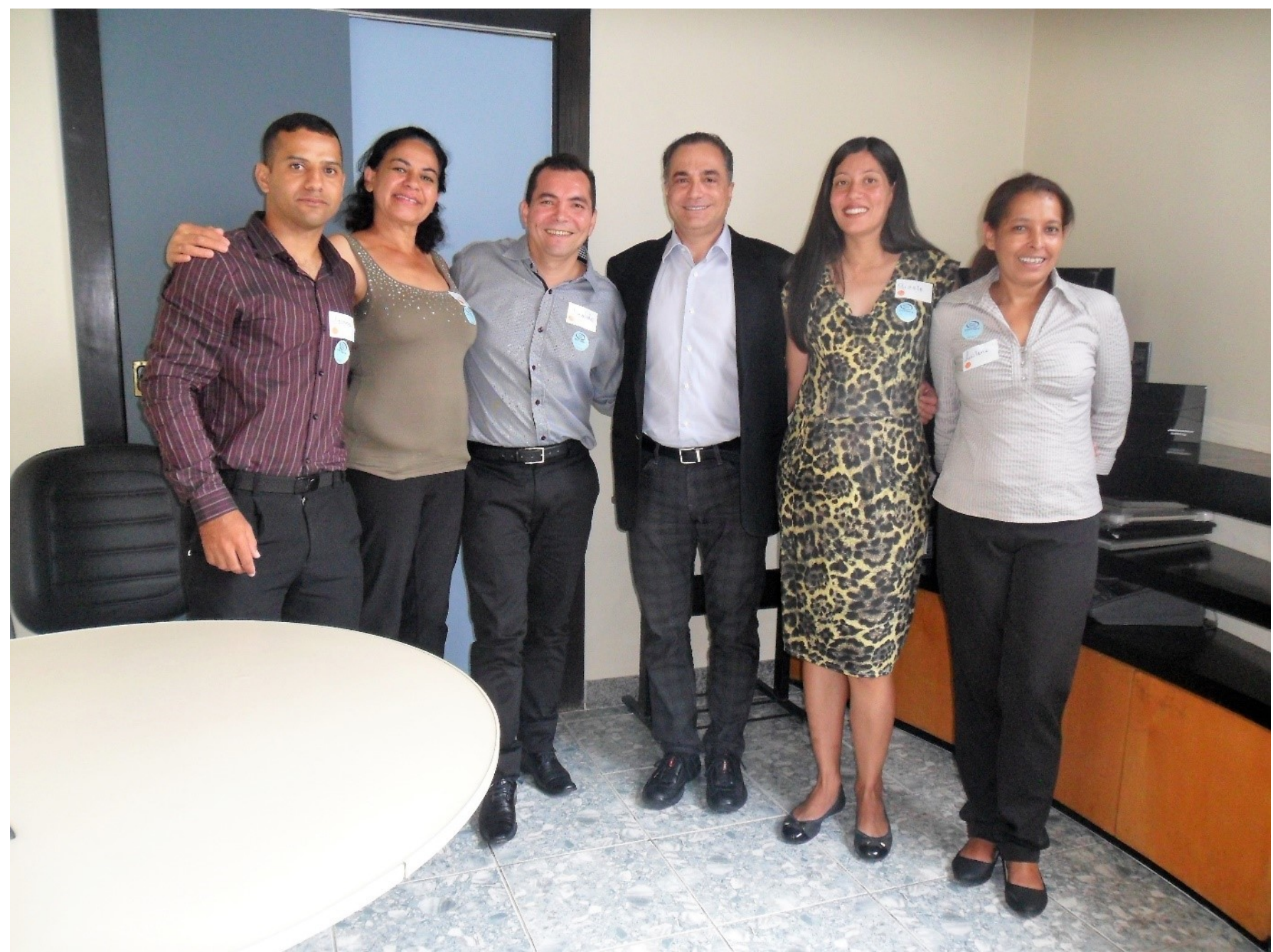

Foto 1- Euler Fuad Nejm com Ângela, Agnaldo, Gizele, Jovane e Lucilene em 10/10/16. Fonte: Autores 2016

[1] Trabalho de Conclusão de Curso apresentado no Curso de Graduação em Administração da Faculdade de Ciências Sociais Aplicadas de Belo Horizonte como requisito parcial para obtenção do título de Bacharel em Administração.

${ }^{[2]}$ Bacharel em Administração de empresas (FACISABH)

${ }^{[3]}$ Graduando em Administração de empresas (FACISABH)

${ }^{[4]}$ Graduando em Administração de Empresas (FACISABH)

${ }^{[5]}$ Graduando em Administração de Empresa (FACISABH)

${ }^{[6]}$ Bacharel em Administração de Empresas (FACISABH), pós-graduando em Gestão Pública (FAEL).

${ }^{[7]}$ Euler Fuad Nejm proprietário e atual presidente da Multi Formato S/A. 
${ }^{[8]}$ CANTILLON, Richard. Ensaio sobre a natureza do comércio em geral. 1755.

[9] SAY, Jean Baptiste. Tratado de economia política. 1888.

${ }^{[10]}$ SCHUMPETER, Joseph Alois. Capitalismo, socialismo e democracia. 1942

${ }^{[11]}$ Dados fornecidos por Euler Fuad Nejm, proprietário e atual presidente da empresa Multi Formato Distribuidora S/A.

[12] São considerados produtos de linha Gourmet ou Premium, os de categorias superiores de consumo, isso pela elevada qualidade, embalagem e/ou produto.

[13] Benchmarking é um processo de comparação de produtos, serviços e práticas empresariais, e é um importante instrumento de gestão das empresas.

\section{PUBLIQUE SEU ARTIGO CIENTÍFICO EM:}

https://www.nucleodoconhecimento.com.br/enviar-artigo-cientifico-para-submissao 